\title{
Science
}

\section{Forest restoration: Transformative trees}

Douglas Sheil, Aida Bargués-Tobella, Ulrik Ilstedt, Pierre L. Ibisch, Anastassia Makarieva, Clive McAlpine, Cindy E. Morris, Daniel Murdiyarso, Antonio D. Nobre, Germán Poveda, Dominick V. Spracklen, Caroline A. Sullivan, Obbe A. Tuinenburg and Ruud J. van der Ent

Science 366 (6463), 316-317.

DOI: $10.1126 /$ science.aay7309

ARTICLE TOOLS

RELATED

CONTENT

REFERENCES

PERMISSIONS http://science.sciencemag.org/content/366/6463/316.2

http://science.sciencemag.org/content/sci/366/6463/317.full

This article cites 8 articles, 2 of which you can access for free http://science.sciencemag.org/content/366/6463/316.2\#BIBL

http://www.sciencemag.org/help/reprints-and-permissions

Use of this article is subject to the Terms of Service

Science (print ISSN 0036-8075; online ISSN 1095-9203) is published by the American Association for the Advancement of Science, 1200 New York Avenue NW, Washington, DC 20005. The title Science is a registered trademark of AAAS.

Copyright @ 2019 The Authors, some rights reserved; exclusive licensee American Association for the Advancement of Science. No claim to original U.S. Government Works 


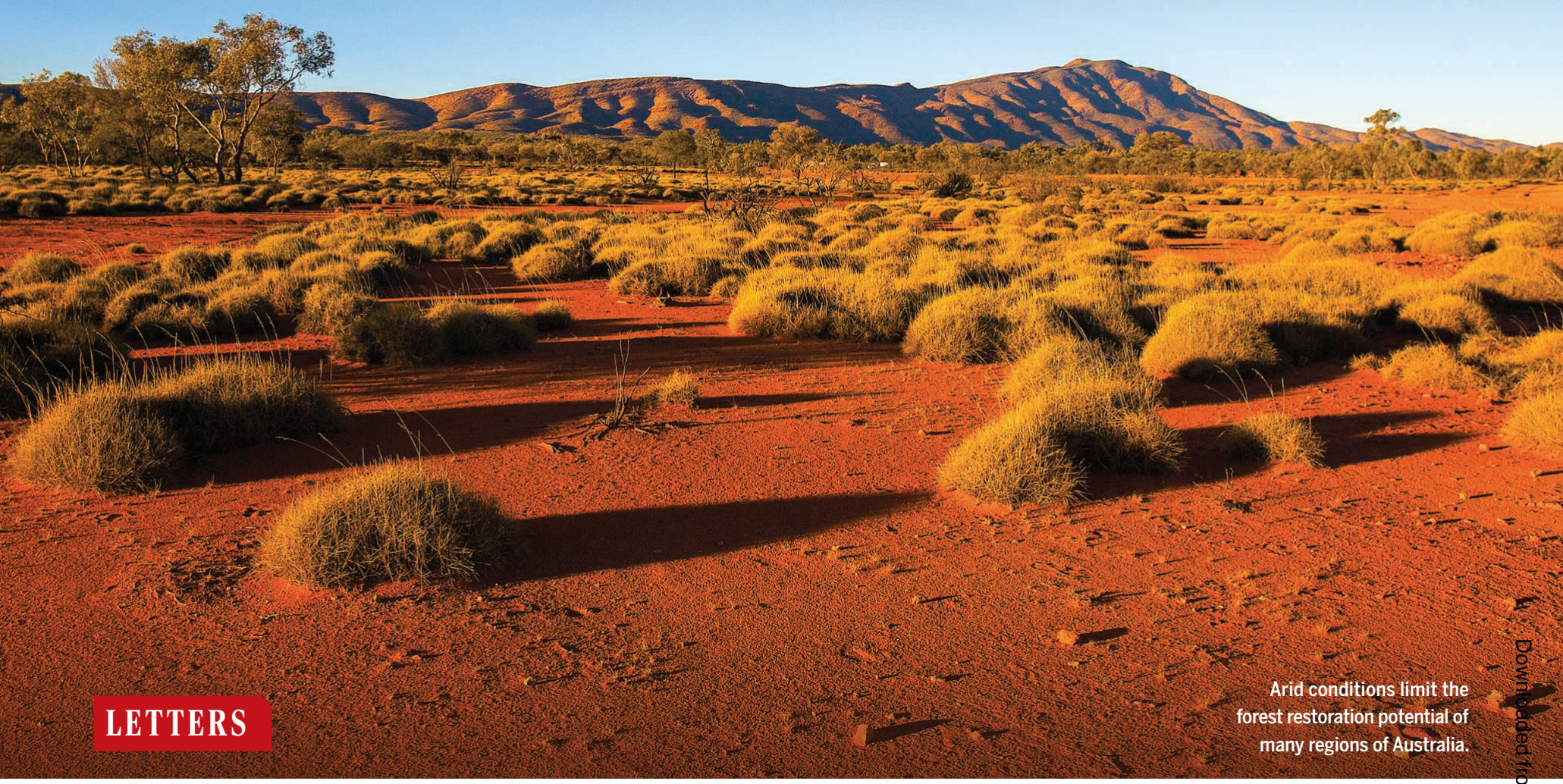

\section{Edited by Jennifer Sills}

\section{Forest restoration: Overlooked constraints}

In their Report "The global tree restoration potential" (5 July, p. 76), J.-F. Bastin et al. use machine learning to derive the carbon storage potential of global tree restoration, which they identify as the most effective climate change mitigation option. However, the study likely overestimates the actual potential by identifying opportunities for increasing canopy cover in environments with obvious environmental or socioeconomic constraints.

In high-latitude regions of Russia, Scandinavia, and North America, permafrost and short growing seasons (1) impair tree growth. In large parts of Australia and other arid and hyperarid regions, salinity, sodicity, hardpans, and moisture limitations prevent tree establishment (2, 3). In African grasslands, infertile soils, grazing animals, water constraints, and wildfires maintain patchy shrub-grass environments (4). In areas with severely degraded soils and biodiversity loss in the Americas and in Asia $(5,6)$, prospects of restoring pre-degradation canopy cover are limited. In grazing lands and production forests, abandoning current uses implies staggering absolute opportunity costs. Finally, Bastin et al. excluded areas classified as urban, but the data set they used (7) fails to recognize some major urban centers and many towns and villages in rural areas (7); more than 2.5 billion people live in areas that Bastin et al. considered eligible for restoration (8), including entire cities, such as Kinshasa, the capital of the Democratic Republic of Congo.

Bastin et al. introduced further overestimation by multiplying tree cover expansion potential by total ecosystem carbon. This operation lowers the baseline by assuming that carbon stock is proportionally related to canopy cover-i.e., that land with no trees contains no carbon. The use of biome-level carbon stock averages, without considering spatial variation, also adds considerable error, especially in alleged high-potential areas, where these averages (154.7 to $282.5 \mathrm{Mg}$ $\mathrm{ha}^{-1}$ ) are approximately 5 times greater than what has been reported in site-specific assessments $(9,10)$.

We appreciate the need for benchmark estimates of carbon storage and restoration potentials, but realistic predictions require tapping expert knowledge to ensure relevant constraints are considered, as well as more rigorous quality control, such as mapping how model validation errors are spatially distributed. Overly hopeful figures produced by models without necessary supervision may misguide the development of climate policy $(11,12)$.

Eike Luedeling ${ }^{1}$, Jan Börner ${ }^{2}$, Wulf Amelung ${ }^{3}$, Katja Schiffers ${ }^{1}$, Keith Shepherd ${ }^{4}$, Todd Rosenstock ${ }^{5}$ ${ }^{1}$ Department of Horticultural Sciences, Institute of Crop Science and Resource Conservation,
University of Bonn, 53121 Bonn, Germany. 2Department of Economics of Sustainable Land Use and Bioeconomy and Center for Development Research, Institute for Food and Resource Economics, University of Bonn, 53115 Bonn, Germany. ${ }^{3}$ Department of Soil Science and Soil Ecology, Institute of Crop Science and Resource Conservation, University of Bonn, 53115 Bonn, Germany. ${ }^{4}$ World Agroforestry Centre, Gigiri, Nairobi, Kenya. ${ }^{5}$ World Agroforestry Centre Kinshasa, Democratic Republic of Congo. ${ }^{*}$ Corresponding author.

Email: luedeling@uni-bonn.de

\section{REFERENCES AND NOTES}

1. J. Obu et al.,Earth-Sci. Rev. 193,299 (2019).

2. FAO and ITPS, "Status of the World's Soil Resources (SWSR)-Main Report: Food and Agriculture Organization of the United Nations and Intergovernmental Technical Panel on Soils" (Rome, Italy, 2015)

3. S. R. Mortonet al., J. Arid Environ. 75, 313 (2011)

4. M. Sankaran et al., Nature 438,846 (2005)

5. M.A. Stocking Science 302,1356 (2003).

6. IPBES, "The IPBES assessment report on land degradation and restoration," L. Montanarella, R. Scholes, A. Brainich, Eds. (Secretariat of the Intergovernmental Science-Policy Platform on Biodiversity and Ecosystem Services, Bonn, Germany, 2018).

7. O. Arino, Global Land Cover Map for 2009, European Space Agency (ESA) \& Université Catholique de Louvain (UCL), PANGAEA, 10.1594/PANGAEA.787668 (GlobCover 2009)

8. Center for International Earth Science Information Network, Columbia University, Gridded Population of the World, Version 4 (GPWv4): Population Density, Revision 11.(2018); https://sedac. ciesin.columbia.edu/ data/set/gpw-v4-population-density-rev11/metadata.

9. D.D. Shirima et al. African J. Ecol. 49, 332 (2011).

10. M. B. Siewert et al. J. Geophys. Res. Biogeosci. 120 1973 (2015).

11. M.D. Mastrandrea et al.,"Guidance note for lead authors of the IPCC Fifth Assessment Report on Consistent Treatment of Uncertainties"(IPCC, 2010); https://wg1. ipcc.ch/AR6/documents/AR5_Uncertainty_Guidance Note pdf

12. C.M.Andersonetal., Science 363, 933 (2019). 


\section{Forest restoration: Expanding agriculture}

In their Report "The global tree restoration potential" (5 July, p. 76), J.-F. Bastin et al. determine the available potential forest restoration area by excluding areas with existing trees, urban settlement, and cropland. However, they overestimate the potential area because they do not account for projected agricultural land expansion or current use of pasture land.

There is evidence from satellite imagery that most of global agricultural land expansion in the previous three decades happened and is still happening on tropical forest land, especially in Brazil and Southeast Asia (1-3). Given that this trend is likely to continue, especially in the highly productive areas in Central and South America, agricultural land expansion must be taken into account when assessing future tree restoration potentials (4-6). Food and Agriculture Organization projections expect an increase of cropland by $7 \%$ until 2030 (7), and evidence suggests an increase in global cropland area between 11 and 26\% until 2050 (8), the latter corresponding to 4 million $\mathrm{km}^{2}$. Based on one approach (4), not using this area for crop production would reduce global crop production by $11 \%$ and increase crop prices by $23 \%$.

Furthermore, Bastin et al. assume that grassland would be available for tree restoration. They choose to ignore the data showing that currently about 30 million $\mathrm{km}^{2}$ of grassland areas are used for extensive livestock production (9). Not utilizing areas for cropland expansion and pasture land requires a higher intensification of agriculture, which in turn is associated with higher agricultural emissions (10) and loss of biodiversity (4).

Bastin et al. do not consider current and future trade-offs with food security and neglect socioeconomic aspects of increasing consumption that arise through population growth, income growth, and preference changes toward more livestock products in fast-growing economies (11). Excluding estimated expansion areas and grazing land reduces the calculated sequestration potential by 19 and $57 \%$, respectively, when applying the carbon densities of the bookkeeping model BLUE (12).

Ruth Delzeit ${ }^{1}$, Julia Pongratz ${ }^{2,3}$, Julia M. Schneider ${ }^{2}$, Franziska Schuenemann ${ }^{1 *}$, Wolfram Mauser ${ }^{2}$,

Florian Zabe ${ }^{2 *}$

${ }^{1}$ Kiel Institute for the World Economy, $24105 \mathrm{Kiel}$

Germany. ${ }^{2}$ Ludwig-Maximilians-University, 80333

Munich, Germany. ${ }^{3}$ Max Planck Institute for

Meteorology, 20146 Hamburg, Germany.

* Corresponding author Email: franziska.

schuenemann@ifw-kiel.de (F.S.); f.zabel@

Imu.de (F.Z.)

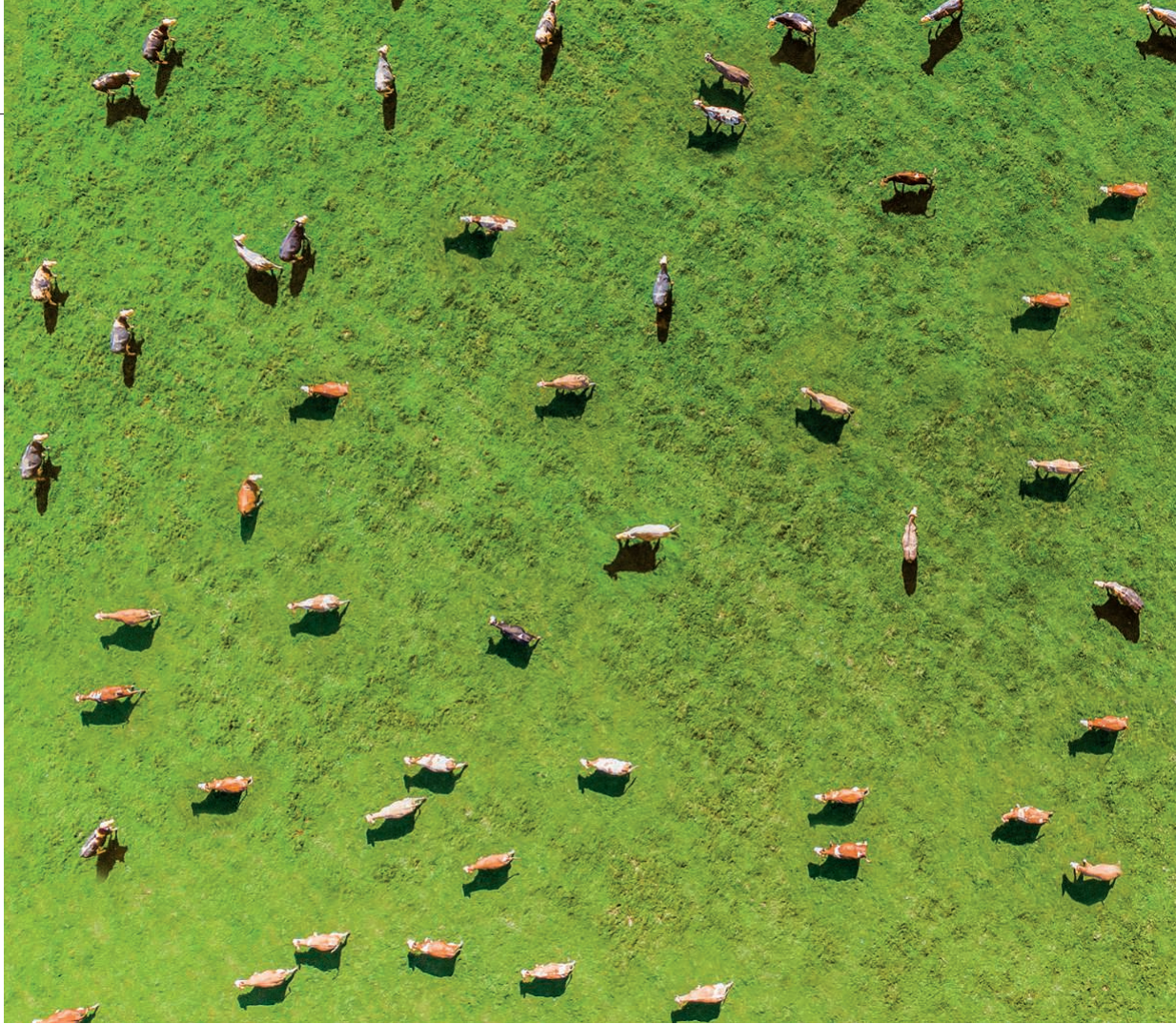

Expanding agricultural land and livestock production could conflict with forest restoration goals.

REFERENCES AND NOTES

1. J.A. Foley et al., Nature 478, 337 (2011)

2. H. K. Gibbs et al.,Proc. Natl.Acad. Sci. U.S.A. 107 $16732(2010)$

3. Z.Zeng etal.,Nat. Geosci. 11,556 (2018).

4. F.Zabel etal., Nat. Commun. 10,2844 (2019)

5. R. Delzeit, F.Zabel, C. Meyer, T. Václavík, Region. Environ. Change 17,1429(2017)

6. A Molotoks et al Glob Change Biol 24, 5895(2018)

7. N. Alexandratos, J. Bruinsma,"World agriculture towards 2030/2050: the 2012 revision," ESA Working Paper No. 12-03 (FAO, Rome, 2012).

8. C. Schmitzet al., Agric. Econ. 45, 69 (2014).

9. N. Ramankutty, A. T. Evan, C. Monfreda, J. A. Foley, Glob. Biogeochem. Cycles 22, GB1003 (2008).

10. C. L. van Beek, B. G. Meerburg, R. L. M. Schils, J. Verhagen, P. J. Kuikman, Environ. Sci. Pol. 13, 89 (2010).

11. F. Schuenemann, R. Delzeit, Schriften der Gesellschaft für Wirtschafts- und Sozialwissenschaften des Landbaues e.V. 64, 185(2019).

12. E. Hansis, S. J. Davis, J. Pongratz, Glob. Biogeochem Cycles 29, 1230 (2015)

10.1126/science.aaz0705

\section{Forest restoration: Transformative trees}

We welcome the attention given to forest and trees by the Report "The global tree restoration potential" (5 July, p. 76), in which J.-F. Bastin et al. study the potential of tree cover to reduce climate change. However, we are concerned by their neglect of the water cycle. They consider how water influences tree cover but disregard how tree cover influences water. Bastin et al. recognize that their extrapolations are not "future projections of potential forest extent" but instead represent potential tree cover "under existing environmental conditions." However, given the influence of forests on their environment, the concept of potential tree cover under current conditions is problematic. Trees influence several of the variables Bastin et al. used to model tree cover, including precipitation quantity, variability, and seasonality, as well as soil moisture and atmospheric water transport (1-4).

While much remains uncertain (2), we know enough to foresee that afforestation and reforestation have potential for both negative and positive hydrological impacts. Negative impacts can result if plantings deplete groundwater and thus exacerbate local water scarcity. Changes can manifest quickly and are a recognized problem with fast-growing monoculture plantations (5). Positive impacts can result when tree cover improves soil and groundwater recharge and storage, such as through suitable species and tree densities (6). Forest cover can also promote rainfall recycling and thus bolster and stabilize regional and downwind rainfall $(1,7,8)$. In suitable circumstances, increased forest cover may even return wetter climates to currently drier regions, expanding the land available for trees (2). These outcomes have profound implications given that reliable access to water is central to achieving the UN Sustainable Development Goals. Accounting for the potentially transformative power of trees for both water and carbon offers crucial constraints as well as vast benefits.

Douglas Sheil, ${ }^{1,2}$ Aida Bargués-Tobella, ${ }^{3,4}$ Ulrik Ilstedt, ${ }^{4}$ Pierre L. Ibisch, ${ }^{5}$ Anastassia Makarieva, ${ }^{6}$ Clive McAlpine, ${ }^{7}$ Cindy E. Morris, ${ }^{8}$ Daniel 
4. J. F. Salazar et al., Hydrol. Earth Syst. Sci.22,1735(2018).

5. R. B. Jacksonet al., Science 310,1944 (2005)

6. U. Ilstedtetal.,Sci.Rep.6.21930 (2016)

7. L.Wang-Erlandsson et al., Hydrol. Earth Syst. Sci. 22 4311(2018)

8. A. Staal et al.,Nat. Clim. Change 8,539(2018).

10.1126/science.aay7309

\section{Response}

Luedeling and colleagues argue that we have overestimated the restoration capacity in several regions of the world. Our model predicts the expected optimal tree cover from a combination of 10 environmental variables that were selected through a variable selection procedure to avoid overfitting issues. As detailed in table $\mathrm{S} 1$ of our supplementary material, these 10 variables include mean annual temperature, temperature of the wettest quarter, annual precipitation, precipitation seasonality, precipitation of the driest quarter, elevation, hillshade, soil organic carbon, sand content, and depth to bedrock. These ecological variables cover average and seasonal variation in climate and variation in topographic and edaphic conditions. As such, we have done everything that is possible to represent all of the conditions raised by Luedeling and colleagues. Of course, cold and dry conditions are among the main limitations for tree growth, and that is why we have represented these environmental constraints in our model to ensure that we do not predict that trees can exist in regions that are too cold or dry.

As explained in the main text, our rigorous k-fold cross-validation (fig. S4A) revealed that our model could explain about $71 \%$ of the variation in tree cover without bias (fig. S3, B and C). This means that our model is unbiased at a global scale, but we do not explain $100 \%$ of the potential tree cover variation. It is consequently possible to find places where we overestimate or underestimate the potential tree cover-particularly in areas where uncertainties are high, as shown in fig S6.

Delzeit and colleagues claim that we overestimate the area available for tree restoration because the expansion of croplands in upcoming decades will reduce the land available for restoration, and because pasture lands are considered as potential land for restoration in our assessment. We agree that, if we continue to expand agricultural land area, there will be a reduction in the land available for restoration. As stated in our analysis, our model estimates the area that is currently available for restoration under present conditions. Of course, any changes in the area of land use will necessarily affect this global total. We exemplified this in our attempts to show how future changes in climate might reduce the area available for restoration. We hope that our analysis can also serve as a stepping stone for future research to evaluate how changes in agricultural land use will affect the potential restoration area.

It is true that we included rangelands in the area available for restoration. Of course, much of this land is used for the grazing of animals and so may not be available for complete forest restoration. However, as mentioned in the Report, several studies suggest that it is possible to increase the current tree cover in these areas without limiting food production $(1,2)$, especially when forest cover is relatively low, as is the case for most of the pasture land in our model.

Because we removed all urban and agricultural land (i.e., we considered a potential increase of tree cover of $0 \%$ in cropland and urban areas), our numbers are likely to underestimate the total area that could currently be covered by trees. Indeed, both croplands and cities constitute great opportunities to increase the current tree cover and to play a major role in mitigating climate change (3-5). We maintain that our global estimate of the land available for restoration is a conservative one, and we encourage local land owners to use our forest restoration potential map in combination with more detailed local-scale estimates of land use when designing effective restoration strategies.

Sheil and colleagues point out that restoring ecosystems might have either positive or negative consequences regarding hydrology. We agree that these effects must be considered as a priority in upcoming research in restoration ecology. Jean-Francois Bastin ${ }^{1 *}$, Yelena Finegold ${ }^{2}$, Claude Garcia $^{3,4}$, Danilo Mollicone ${ }^{2}$, Marcelo Rezende ${ }^{2}$, Devin Routh ${ }^{1}$, Constantin M. Zohner ${ }^{1}$, Thomas W. Crowther ${ }^{1}$ ${ }^{1}$ Crowther Lab, Department of Environmental Systems Science, Institute of Integrative Biology, ETH Zürich, Zürich, Switzerland. ${ }^{2}$ Food and Agriculture Organization of the United Nations, Rome, Italy. ${ }^{3}$ Department of Environmental Systems Science, Institute of Integrative Biology, ETH Zürich, Zürich, Switzerland. ${ }^{4}$ Centre de Coopération Internationale en la Recherche Agronomique pour le Développement (CIRAD), UR Forest and Societies, Montpellier, France. *Corresponding author. Email: bastin.jf@gmail.com

\section{REFERENCES AND NOTES}

1. K.-H. Erbetal., Nature 553,73 (2017),

2. K.-H. Erbetal., Nat. Commun. 7, 11382 (2016)

3. A. Albrecht, S. T. Kandji, Agric. Ecosyst. Environ. 99 15 (2003).

4. P. K. Ramachandran Nair, B. Mohan Kumar, V. D. Nair, J. Plant Nutr. Soil Sci. 172, 10 (2009)

5. G. Manolietal., Nature 573,55 (2019).

10.1126/science.aaz2148
1. D. Ellisonet al., Glob. Environ. Change 43,51 (2017),

2. D. Sheil, For. Ecosyst. 5, 1(2018).

3. J.S. Wrightetal.,Proc. Natl. Acad. Sci. U.S.A.114 8481 (2017) 


\section{TECHNICAL COMMENT ABSTRACTS}

Comment on "The global tree restoration potential" Pierre Friedlingstein, Myles Allen, Josep G. Canadell, Glen P. Peters, Sonia I. Seneviratne Bastin et al. (Reports, 5 July 2019, p. 76) claim that global tree restoration is the most effective climate change solution to date, with a reported carbon storage potential of 205 gigatonnes of carbon. However, this estimate and its implications for climate mitigation are inconsistent with the dynamics of the global carbon cycle and its response to anthropogenic carbon dioxide emissions. Full text: dx.doi.org/10.1126/science.aay8060

Comment on "The global tree restoration potential" Joseph W. Veldman, Julie C. Aleman, Swanni T. Alvarado, T. Michael Anderson, Sally Archibald, William J. Bond, Thomas W. Boutton, Nina Buchmann, Elise Buisson, Josep G. Canadell, Michele de Sá Dechoum, Milton H. Diaz-Toribio, Giselda Durigan, John J. Ewel, G. Wilson Fernandes, Alessandra Fidelis, Forrest Fleischman, Stephen P. Good, Daniel M. Griffith, Julia-Maria Hermann, William A. Hoffmann, Soizig Le Stradic, Caroline E. R. Lehmann, Gregory Mahy, Ashish N. Nerlekar, Jesse B. Nippert, Reed F. Noss, Colin P. Osborne, Gerhard E. Overbeck, Catherine L. Parr, Juli G. Pausas, R. Toby Pennington, Michael P. Perring, Francis E. Putz, Jayashree Ratnam, Mahesh Sankaran, Isabel B. Schmidt, Christine B. Schmitt,
Fernando A. 0. Silveira, A. Carla Staver, Nicola Stevens, Christopher Still, Caroline A. E. Strömberg, Vicky M. Temperton, J. Morgan Varner, Nicholas P. Zaloumis

Bastin et al.'s estimate (Reports, 5 July 2019, p. 76) that tree planting for climate change mitigation could sequester 205 gigatonnes of carbon is approximately five times too large. Their analysis inflated soil organic carbon gains, failed to safeguard against warming from trees at high latitudes and elevations, and considered afforestation of savannas, grasslands, and shrublands to be restoration.

Full text: dx.doi.org/10.1126/science.aay7976

Comment on "The global tree restoration potential" Simon L. Lewis, Edward T. A. Mitchard, Colin Prentice, Mark Maslin, Ben Poulter Bastin et al. (Reports, 5 July 2019, p. 76) state that the restoration potential of new forests globally is 205 gigatonnes of carbon, conclude that "global tree restoration [is] our most effective climate change solution to date," and state that climate change will drive the loss of 450 million hectares of existing tropical forest by 2050 . Here we show that these three statements are incorrect.

Full text: $d x$.doi.org/10.1126/science.aaz0388
Response to Comments on "The global tree restoration potential"

Jean-Francois Bastin, Yelena Finegold, Claude Garcia, Nick Gellie, Andrew Lowe, Danilo Mollicone, Marcelo Rezende, Devin Routh, Moctar Sacande, Ben Sparrow, Constantin M. Zohner, Thomas W. Crowther Our study quantified the global tree restoration potential and its associated carbon storage potential under existing climate conditions. We received multiple technical comments, both supporting and disputing our findings. We recognize that several issues raised in these comments are worthy of discussion. We therefore provide a detailed common answer where we show that our original estimations are accurate. Full text: dx.doi.org/10.1126/science.aay 8108

Comment on "The global tree restoration potential" Alan Grainger, Louis R. Iverson, Gregg H. Marland, Anantha Prasad

Bastin et al. (Reports, 5 July 2019, p. 76) neglect considerable research into forestbased climate change mitigation during the 1980s and 1990s. This research supports some of their findings on the area of land technically suitable for expanding tree cover and can be used to extend their analysis to include the area of actually available land and operational feasibility.

Full text: dx.doi.org/10.1126/science.aay8334

\section{The Best Antibody Discovery Technology Is Now at Your Fingertips}

\section{Trianni Mouse Antibodies are a Match for Humans}

The Trianni Mouse ${ }^{T M}$ platform is a transgenic antibody discovery platform offering the entire human variable gene diversity in a single organism.

The $V(D) J$ gene segments in The Trianni Mouse are chimeric, but the variable domains of antibodies made by the mouse are entirely human. The result is human antibody leads generated from antibody genes optimized for function in the mouse.

To learn more about this innovative platform, visit Trianni.com.
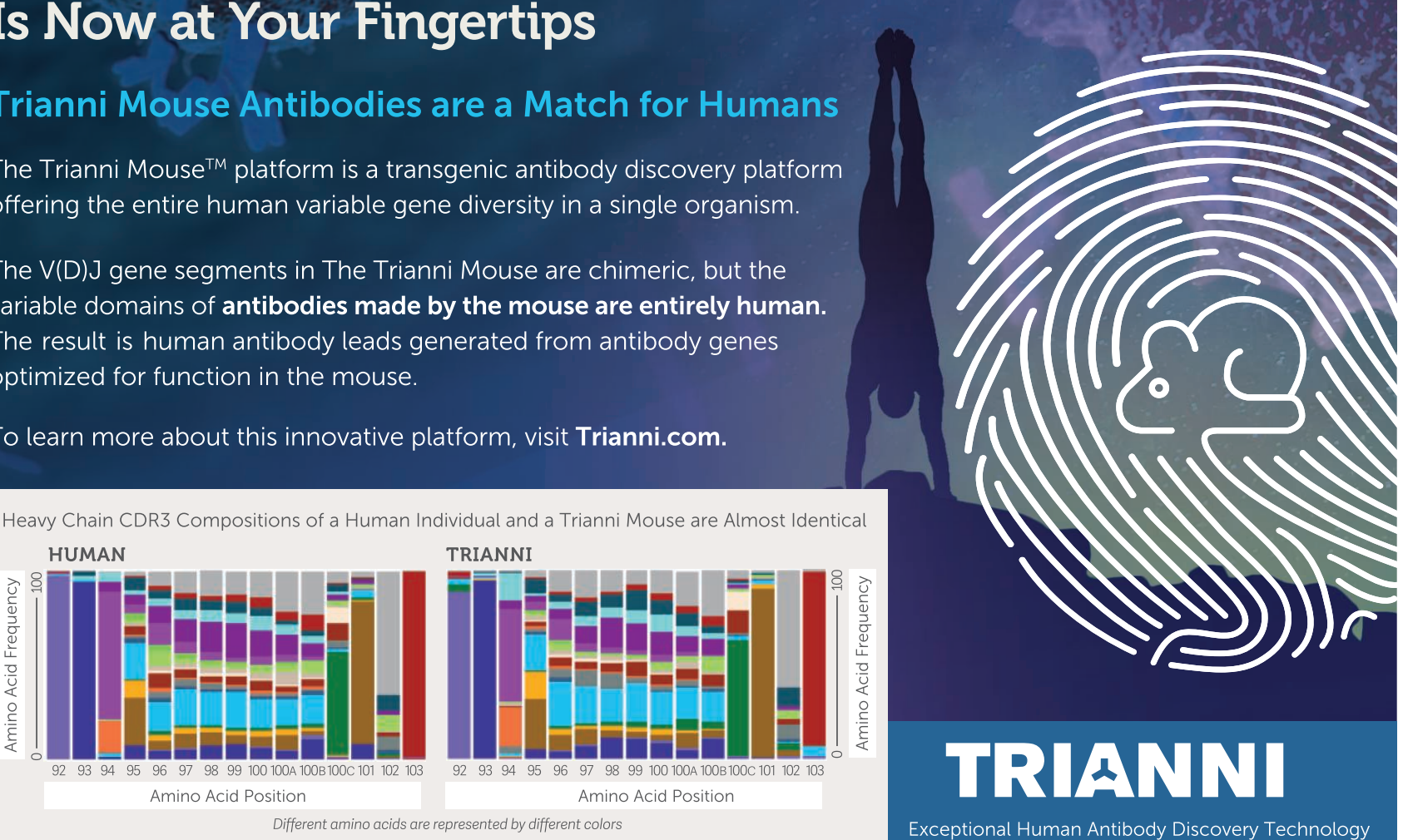


\title{
Comment on "The global tree restoration potential"
}

\author{
Pierre Friedlingstein ${ }^{1 *}$, Myles Allen², Josep G. Canadell ${ }^{3}$, Glen P. Peters ${ }^{4}$, Sonia I. Seneviratne ${ }^{5}$
}

${ }^{1}$ College of Engineering, Mathematics and Physical Sciences, University of Exeter, Exeter EX4 4QE, UK. ${ }^{2}$ Department of Physics, University of Oxford, Oxford OX1 3PJ, UK. ${ }^{3} \mathrm{Global}$ Carbon Project, CSIRO Oceans and Atmosphere, Canberra, ACT 2601, Australia. ${ }^{4} \mathrm{CICERO}$ Center for International Climate Research, Oslo 0349, Norway. ${ }^{5}$ Institute for Atmospheric and Climate Science, ETH Zurich, 8092 Zurich, Switzerland.

${ }^{*}$ Corresponding author. Email: p.friedlingstein@exeter.ac.uk

Bastin et al. (Reports, 5 July 2019, p. 76) claim that global tree restoration is the most effective climate change solution to date, with a reported carbon storage potential of 205 gigatonnes of carbon. However, this estimate and its implications for climate mitigation are inconsistent with the dynamics of the global carbon cycle and its response to anthropogenic carbon dioxide emissions.

In their recent report, Bastin et al. (1) claimed that their study "highlights global tree restoration as our most effective climate change solution to date." The authors estimate that one could restore about 0.9 billion ha of canopy cover, which could store $205 \mathrm{GtC}$ (gigatonnes of carbon) in areas that would naturally support woodlands and forests. The authors claim that "reaching this maximum restoration potential would reduce a considerable proportion of the global anthropogenic carbon burden $(\sim 300 \mathrm{GtC})$ to date. This places ecosystem restoration as the most effective solution at our disposal to mitigate climate change." We believe this conclusion is wrong because of the authors' misunderstanding of both carbon storage potential and the global carbon cycle response to anthropogenic emissions.

First, Bastin et al. compared their estimate of $205 \mathrm{GtC}$ with "the global anthropogenic carbon burden" of about 300 $\mathrm{GtC}$ to date. The $300 \mathrm{GtC}$ figure seems to refer to the historical increase in atmospheric $\mathrm{CO}_{2}$ (expressed in their paper in units of mass, GtC, as opposed to the usual units of concentration, ppm), which is only about half of the historical anthropogenic emissions of about $600 \mathrm{GtC}$ (2). Only about 45\% of these emissions remain in the atmosphere; the rest has been absorbed by the ocean and land ecosystems. The ratio of atmospheric $\mathrm{CO}_{2}$ increase to anthropogenic $\mathrm{CO}_{2}$ emissions, called the airborne fraction, is relatively constant over the historical record and was described more than 40 years ago (3). Assuming that fossil fuel emissions continue at some level for the duration of a forest restoration program as suggested by Bastin et al., net anthropogenic emissions over this period will be the difference between the fossil fuel emissions and the net biospheric uptake due to forest restoration. The balance between future emissions and future uptake will be subject to the same airborne fraction of around $45 \%(4,5)$. The authors should have estimated the atmospheric carbon removal from forest restoration as the potential carbon storage multiplied by the airborne fraction, reducing by about $45 \%$ the reported impact of this forest restoration option on the atmospheric $\mathrm{CO}_{2}$ growth rate. $\mathrm{Al}$ ternatively, the potential carbon removal from forest restoration could be directly compared to cumulative anthropogenic emissions to date (about $600 \mathrm{GtC}$ ), but not the fraction remaining in the atmosphere.

Second, the 205 GtC figure is obtained from the potential canopy cover spatial distribution (as shown in their figure $2, \mathrm{~B}$ and $\mathrm{C}$ ) and the carbon densities across the major biomes of the world (table S2, with distribution shown in figure S2). From table S2, it appears that the authors simply multiplied the potential canopy cover (in Mha) by the carbon densities (in tC/ha) of the biome currently in these regions to estimate potential carbon storage. By doing so, they would, in effect, ignore the carbon that is currently stored in those regions. The right approach is to estimate the carbon storage potential as the difference between carbon potentially stored by a forest and the carbon currently stored by the existing ecosystem-for example, forest versus tundra (assuming that a forest could be sustained in the Arctic climate of the tundra biome). From the carbon densities given in table $\mathrm{S} 2$ for each biome, it is clear that the potential carbon storage would be substantially lower than reported. Boreal forests can only store about $15 \%$ more carbon than tundra; temperate (tropical) forests are given the same carbon density as temperate (tropical) grasslands, implying no clear carbon gain from forest restoration.

Moreover, forests affect climate through biophysical feedbacks, such as changes in albedo or evapotranspiration (6), which can counteract the cooling effect from $\mathrm{CO}_{2}$ uptake. It is well established, for instance, that afforestation in snow-covered regions may lead to weak local cooling, or even to warming, as the positive radiative forcing induced by decreases in albedo can offset the negative radiative forc- 
ing from carbon sequestration [e.g., $(7,8)]$. These biophysical feedbacks were not discussed in the article and could substantially reduce the potential of forest reforestation in some of the considered regions.

Third, regardless of the exact amount of carbon that could be stored via forest restoration, this solution can only temporarily delay future warming. The $205 \mathrm{GtC}$ proposed by the authors is equal to about 20 years of global anthropogenic $\mathrm{CO}_{2}$ emissions at the current emission rate of about 10 GtC/year (2). Without radical reductions in fossil carbon emissions, forest restoration can only offset a share of future emissions and has limited potential. The only long-term and sustainable way to stabilize the climate at any temperature target is to reduce anthropogenic $\mathrm{CO}_{2}$ emissions to zero (over the coming 30 to 50 years to meet the temperature targets of the Paris Climate Agreement) (9).

Finally, the paper does not provide any evidence that ecosystem restoration is "the most effective solution at our disposal to mitigate climate change." Analyses showing the carbon mitigation potential of planting trees have been available for the past two decades [e.g., (10)], yet there has been very limited adoption of such a strategy because of concerns about unintended consequences (e.g., water availability) and complex land rights. In contrast, energy efficiency and deployment of nonfossil energy sources have helped reduce emissions in the past (11) and are key characteristics of deep mitigation pathways even when large-scale $\mathrm{CO}_{2}$ removal is deployed (12). The literature indicates that a multitude of mitigation measures are needed [e.g., $(9,13)]$, and it is unlikely that any measure would be the "most effective."

Bastin et al. strongly overestimate the potential of forest restoration to mitigate climate change. The claim that global tree restoration is our most effective climate change solution is simply incorrect scientifically and dangerously misleading.

\section{REFERENCES}

1. J.-F. Bastin, Y. Finegold, C. Garcia, D. Mollicone, M. Rezende, D. Routh, C. M. Zohner, T. W. Crowther, The global tree restoration potential. Science 365, 7679 (2019). doi:10.1126/science.aax0848 Medline

2. C. Le Quéré, R. M. Andrew, P. Friedlingstein, S. Sitch, J. Pongratz, A. C. Manning, J. I. Korsbakken, G. P. Peters, J. G. Canadell, R. B. Jackson, T. A. Boden, P. P. Tans, O. D. Andrews, V. K. Arora, D. C. E. Bakker, L. Barbero, M. Becker, R. A. Betts, L. Bopp, F. Chevallier, L. P. Chini, P. Ciais, C. E. Cosca, J. Cross, K. Currie, T. Gasser, I. Harris, J. Hauck, V. Haverd, R. A. Houghton, C. W. Hunt, G. Hurtt, T. Ilyina, A. K. Jain, E. Kato, M. Kautz, R. F. Keeling, K. Klein Goldewijk, A. Körtzinger, P. Landschützer, N. Lefèvre, A. Lenton, S. Lienert, I. Lima, D. Lombardozzi, N. Metzl, F. Millero, P. M. S. Monteiro, D. R. Munro, J. E. M. S. Nabel, S. Nakaoka, Y. Nojiri, X. A. Padin, A. Peregon, B. Pfeil, D. Pierrot, B. Poulter, G. Rehder, J. Reimer, C. Rödenbeck, J. Schwinger, R. Séférian, I. Skjelvan, B. D. Stocker, H. Tian, B. Tilbrook, F. N. Tubiello, I. T. van der Laan-Luijkx, G. R. van der Werf, S. van Heuven, N. Viovy, N. Vuichard, A. P. Walker, A. J. Watson, A. J. Wiltshire, S. Zaehle, D. Zhu, Global Carbon Budget 2017. Earth Syst. Sci. Data 10, 405-448 (2018). doi:10.5194/essd-10-405-2018
3. C. D. Keeling, R. B. Bacastow, A. E. Bainbridge, C. A. Ekdahl Jr., P. R. Guenther, L. S. Waterman, J. F. S. Chin, Atmospheric carbon dioxide variations at Mauna Loa Observatory, Hawaii. Tellus 28, 538-551 (1976). doi:10.1111/i.21533490.1976.tb00701.x

4. C. D. Jones, P. Ciais, S. J. Davis, P. Friedlingstein, T. Gasser, G. P. Peters, J. Rogelj, D. P. van Vuuren, J. G. Canadell, A. Cowie, R. B. Jackson, M. Jonas, E. Kriegler, E. Littleton, J. A. Lowe, J. Milne, G. Shrestha, P. Smith, A. Torvanger, A. Wiltshire, Simulating the Earth system response to negative emissions. Environ. Res. Lett. 11, 095012 (2016). doi:10.1088/1748-9326/11/9/095012

5. K. B. Tokarska, K. Zickfeld, The effectiveness of net negative carbon dioxide emissions in reversing anthropogenic climate change. Environ. Res. Lett. 10, 094013 (2015). doi:10.1088/1748-9326/10/9/094013

6. R. G. Anderson, J. G. Canadell, J. T. Randerson, R. B. Jackson, B. A. Hungate, D. D. Baldocchi, G. A. Ban-Weiss, G. B. Bonan, K. Caldeira, L. Cao, N. S. Diffenbaugh, K. R. Gurney, L. M. Kueppers, B. E. Law, S. Luyssaert, T. L. O'Halloran, Biophysical considerations in forestry for climate protection. Front. Ecol. Environ. 9, 174-182 (2011). doi:10.1890/090179

7. R. A. Betts, Offset of the potential carbon sink from boreal forestation by decreases in surface albedo. Nature 408, 187-190 (2000). doi:10.1038/35041545 Medline

8. R. Alkama, A. Cescatti, Biophysical climate impacts of recent changes in global forest cover. Science 351, 600-604 (2016). doi:10.1126/science.aac8083 Medline

9. IPCC, Summary for policymakers. In Global Warming of $1.5^{\circ} \mathrm{C}$ : An IPCC Special Report on the Impacts of Global Warming of $1.5^{\circ} \mathrm{C}$ Above Pre-Industrial Levels and Related Global Greenhouse Gas Emission Pathways, in the Context of Strengthening the Global Response to the Threat of Climate Change, Sustainable Development, and Efforts to Eradicate Poverty, V. Masson-Delmotte et al., Eds. (World Meteorological Organization, Geneva, 2018).

10. IPCC, Land Use, Land-Use Change, and Forestry: A Special Report of the IPCC, R. T. Watson et al., Eds. (Cambridge Univ. Press, 2000); www.ipcc.ch/report/landuse-land-use-change-and-forestry/.

11. C. Le Quéré, J. I. Korsbakken, C. Wilson, J. Tosun, R. Andrew, R. J. Andres, J. G. Canadell, A. Jordan, G. P. Peters, D. P. van Vuuren, Drivers of declining $\mathrm{CO}_{2}$ emissions in 18 developed economies. Nat. Clim. Chang. 9, 213-217 (2019). doi:10.1038/s41558-019-0419-7

12. R. B. Jackson, C. Le Quéré, R. M. Andrew, J. G. Canadell, J. I. Korsbakken, Z. Liu, G. P. Peters, B. Zheng, Global energy growth is outpacing decarbonization. Environ. Res. Lett. 13, 120401 (2018). doi:10.1088/1748-9326/aaf303

13. IPCC, Climate Change 2014: Synthesis Report. Contribution of Working Groups I, II and III to the Fifth Assessment Report of the Intergovernmental Panel on Climate Change (2014); www.ipcc.ch/site/assets/uploads/2018/05/SYR_AR5_FINAL_full_wcover.pdf.

\section{ACKNOWLEDGMENTS}

P.F., M.A., G.P.P., and S.I.S. acknowledge funding from the European Union's Horizon 2020 research and innovation program under grant agreement no. 821003. G.P.P. also received funding from the European Commission through grant no. 821003 (CCiCC)

19 July 2019; accepted 27 September 2019

Published online 18 October 2019

10.1126/science.aay8060 


\section{Science}

\section{Comment on "The global tree restoration potential"}

Pierre Friedlingstein, Myles Allen, Josep G. Canadell, Glen P. Peters and Sonia I. Seneviratne

Science 366 (6463), eaay8060

DOI: $10.1126 /$ science.aay8060

ARTICLE TOOLS

RELATED

CONTENT

REFERENCES

PERMISSIONS http://science.sciencemag.org/content/366/6463/eaay8060

http://science.sciencemag.org/content/sci/365/6448/76.full http://science.sciencemag.org/content/sci/366/6463/eaay8108.full http://science.sciencemag.org/content/sci/366/6463/eaay7976.full http://science.sciencemag.org/content/sci/366/6463/eaaz0388.full

This article cites 10 articles, 2 of which you can access for free http://science.sciencemag.org/content/366/6463/eaay8060\#BIBL

http://www.sciencemag.org/help/reprints-and-permissions

Use of this article is subject to the Terms of Service

Science (print ISSN 0036-8075; online ISSN 1095-9203) is published by the American Association for the Advancement of Science, 1200 New York Avenue NW, Washington, DC 20005. The title Science is a registered trademark of AAAS.

Copyright (C) 2019 The Authors, some rights reserved; exclusive licensee American Association for the Advancement of Science. No claim to original U.S. Government Works 


\title{
Comment on "The global tree restoration potential"
}

\author{
Joseph W. Veldman ${ }^{1,2 *}$, Julie C. Aleman ${ }^{1,3}$, Swanni T. Alvarado ${ }^{4,5}$, T. Michael Anderson ${ }^{6}$, \\ Sally Archibald 7 , William J. Bond ${ }^{8}$, Thomas W. Boutton ${ }^{1}$, Nina Buchmann ${ }^{9}$, Elise Buisson ${ }^{10}$, \\ Josep G. Canadell' ${ }^{11}$, Michele de Sá Dechoum ${ }^{12}$, Milton H. Diaz-Toribio ${ }^{13}$, Giselda Durigan ${ }^{14}$, \\ John J. Ewel ${ }^{13}$, G. Wilson Fernandes ${ }^{15}$, Alessandra Fidelis ${ }^{16}$, Forrest Fleischman ${ }^{17}$, Stephen P. Good ${ }^{18}$, \\ Daniel M. Griffith ${ }^{19}$, Julia-Maria Hermann ${ }^{20}$, William A. Hoffmann ${ }^{21}$, Soizig Le Stradic ${ }^{22}$, \\ Caroline E. R. Lehmann ${ }^{23,24}$, Gregory Mahy $^{25}$, Ashish N. Nerlekar ${ }^{1}$, Jesse B. Nippert ${ }^{26}$, Reed F. Noss ${ }^{27}$, \\ Colin P. Osborne ${ }^{28}$, Gerhard E. Overbeck ${ }^{29}$, Catherine L. Parr ${ }^{7,30,31}$, Juli G. Pausas ${ }^{32}$, \\ R. Toby Pennington ${ }^{23,33}$, Michael P. Perring ${ }^{34,35}$, Francis E. Putz ${ }^{13}$, Jayashree Ratnam ${ }^{36}$, \\ Mahesh Sankaran $^{37,38}$, Isabel B. Schmidt ${ }^{39}$, Christine B. Schmitt ${ }^{40,41}$, Fernando A. O. Silveira ${ }^{42}$, \\ A. Carla Staver ${ }^{43}$, Nicola Stevens ${ }^{44}$, Christopher J. Still ${ }^{45}$, Caroline A. E. Strömberg ${ }^{46}$, \\ Vicky M. Temperton ${ }^{47}$, J. Morgan Varner ${ }^{48}$, Nicholas P. Zaloumis ${ }^{49}$
}

1Department of Ecosystem Science and Management, Texas A\&M University, College Station, TX 77843, USA. ${ }^{2}$ Instituto Boliviano de Investigación Forestal, Casilla 6204, Santa Cruz, Bolivia. ${ }^{3}$ Département de Géographie, Université de Montréal, Montreal, QC H3C 3J7, Canada. ${ }^{4}$ Programa de Pós-graduação em Agricultura e Ambiente, Universidade Estadual de Maranhão (UEMA), Balsas, Maranhão, Brazil. ${ }^{5}$ Programa de Pós-graduação em Geografia, Natureza e Dinâmica do Espaço, Universidade Estadual de Maranhão (UEMA), São Luis, Maranhão, Brazil. ${ }^{6}$ Department of Biology, Wake Forest University, Winston-Salem, NC 27109, USA. ${ }^{7}$ Centre for African Ecology, School of Animal, Plant and Environmental Sciences, University of the Witwatersrand, Johannesburg 2050, South Africa. ${ }^{8}$ Department of Biological Sciences, University of Cape Town, Rondebosch, South Africa. ${ }^{9}$ Department of Environmental Systems Science, ETH Zurich, 8092 Zurich, Switzerland. ${ }^{10}$ Avignon Université, IMBE, CNRS, IRD, Aix Marseille Université, Marseille, France. ${ }^{11}$ Global Carbon Project, CSIRO Oceans and Atmosphere, Canberra, ACT 2601, Australia. ${ }^{2}$ Departamento de Ecologia e Zoologia, Programa de Pós-graduação em Ecologia, Universidade Federal de Santa Catarina, Florianopolis, Santa Catarina 88040-900, Brazil. ${ }^{13}$ Department of Biology, University of Florida, Gainesville, FL 32611, USA. ${ }^{14}$ Floresta Estadual de Assis, Instituto Florestal do Estado de São Paulo, São Paulo 19807-300, Brazil. ${ }^{15}$ Departamento de Biologia Geral/ICB, Universidade Federal de Minas Gerais, Belo Horizonte, MG 30161, Brazil. ${ }^{16}$ Lab of Vegetation Ecology, Instituto de Biociências, Universidade Estadual Paulista (UNESP), Rio Claro 13506-900, Brazil. ${ }^{17}$ Department of Forest Resources, University of Minnesota, St. Paul, MN 55108, USA. ${ }^{18}$ Department of Biological and Ecological Engineering, Oregon State University, Corvallis, OR 97330, USA. ${ }^{19}$ Forest Ecosystems and Society, Oregon State University, Corvallis, OR 97331, USA. ${ }^{20}$ Environmental Management, Evangelical Lutheran Church District of Rendsburg-Eckernfoerde, Rendsburg, Germany. ${ }^{21}$ Department of Plant and Microbial Biology, North Carolina State University, Raleigh, NC 27695, USA. ${ }^{22}$ Chair of Restoration Ecology, Department Ecology and Ecosystem Management, Technische Universität München, 85354 Freising, Germany. ${ }^{23}$ Royal Botanic Garden Edinburgh, Edinburgh EH3 5LR, UK. ${ }^{24}$ School of GeoSciences, University of Edinburgh, Edinburgh EH9 3FF, UK. ${ }^{25}$ Terra Research Unit, Biodiversity and Landscape, Gembloux Agro-Bio Tech, University of Liège, Gembloux, Belgium. ${ }^{26}$ Division of Biology, Kansas State University, Manhattan, KS 66506, USA. ${ }^{27}$ Florida Institute for Conservation Science, Siesta Key, FL 34242, USA. ${ }^{28}$ Department of Animal and Plant Sciences, University of Sheffield, Sheffield S10 2TN, UK. ${ }^{29}$ Department of Botany, Universidade Federal do Rio Grande do Sul, Porto Alegre, RS 91501-970, Brazil. ${ }^{30}$ School of Environmental Sciences, University of Liverpool, Liverpool L69 3GP, UK. ${ }^{31}$ Department of Zoology and Entomology, University of Pretoria, Pretoria, South Africa. ${ }^{32}$ Desertification Research Center (CIDE-CSIC), Valencia, Spain. ${ }^{33}$ Geography, University of Exeter, Exeter EX4 4QE, UK. ${ }^{34}$ Forest and Nature Lab, Department of Environment, Ghent University, Ghent, Belgium. ${ }^{35}$ Ecosystem Restoration and Intervention Ecology Research Group, School of Biological Sciences, University of Western Australia, Crawley, WA 6009, Australia. ${ }^{36}$ Wildlife Biology and Conservation Program, National Centre for Biological Sciences, GKVK Campus, Bengaluru 560065, India. ${ }^{37}$ National Centre for Biological Sciences, TIFR, Bengaluru 560065, India. ${ }^{38}$ School of Biology, University of Leeds, Leeds LS2 9JT, UK. ${ }^{39}$ Departamento de Ecologia, Universidade de Brasília, Campus Universitário Darcy Ribeiro, Brasília, DF 70910-900, Brazil. ${ }^{40}$ Center for Development Research (ZEF), University of Bonn, Bonn, Germany. ${ }^{41}$ Chair of Nature Conservation and Landscape Ecology, University of Freiburg, Freiburg, Germany. ${ }^{42}$ Departamento de Genética, Ecologia e Evolução, Universidade Federal de Minas Gerais, Belo Horizonte 31270-901, Brazil. ${ }^{43}$ Ecology and Evolutionary Biology, Yale University, New Haven, CT 06511, USA. ${ }^{44}$ Department of Botany and Zoology, University of Stellenbosch, Stellenbosch 7602, South Africa. ${ }^{45}$ College of Forestry, Oregon State University, Corvallis, OR 97331, USA. ${ }^{46}$ Department of Biology and Burke Museum of Natural History and Culture, University of Washington, Seattle, WA 98105, USA. ${ }^{47}$ Institute of Ecology, Faculty of Sustainability, Leuphana University Lüneburg, 21335 Lüneburg, Germany. ${ }^{48}$ Tall Timbers Research Station and Land Conservancy, Tallahassee, FL 32312, USA. ${ }^{49}$ Unaffiliated scholar, Cape Town 7708, South Africa.

*Corresponding author. Email: veldman@tamu.edu

Bastin et al.'s estimate (Reports, 5 July 2019, p. 76) that tree planting for climate change mitigation could sequester 205 gigatonnes of carbon is approximately five times too large. Their analysis inflated soil organic carbon gains, failed to safeguard against warming from trees at high latitudes and elevations, and considered afforestation of savannas, grasslands, and shrublands to be restoration.

Bastin et al. (I) used remote sensing and machine learning to estimate that global "tree restoration" could sequester 205 gigatonnes of carbon (GtC). If accurate and achievable, this would constitute an astounding accomplishment, equal to 20 times the current annual fossil fuel emissions (10 GtC/year) (2) and about one-third of total historical anthro- 
pogenic emissions (660 GtC) (2). Unfortunately, key assumptions and data underlying Bastin et al.'s analyses are incorrect, resulting in a factor of 5 overestimate of the potential for new trees to capture carbon and mitigate climate change. We show that Bastin et al. (i) overestimated soil carbon gains from increased tree cover by a factor of 2 ; (ii) modeled new tree cover in regions where trees reduce albedo and increase climate warming (3, 4); and (iii) relied heavily on afforestation of grasslands and savannasbiodiverse ecosystems where fires and large herbivores have maintained low tree cover for millions of years $(5,6)$.

Bastin et al.'s inflation of soil carbon gains resulted in a $\sim 98$ GtC overestimate of potential carbon sequestration (Table 1). They mistakenly assumed that treeless areas have no soil organic carbon (SOC) and that SOC increases in direct (1:1) proportion to tree cover. The contribution of SOC to total carbon stocks is substantial in most terrestrial ecosystems. In humid tropical savannas, for example, $86 \%$ of all carbon is in soils (174 tonnes of SOC per hectare) (7). In boreal forests, $64 \%$ of carbon occurs in soils (8). North American grasslands can store as much carbon in soil (9) as tropical forests store as biomass (8). In Table 1, we display SOC-corrected carbon sequestration estimates that use more realistic (literature-derived) values for the changes in SOC that occur with afforestation and reforestation.

In addition to the SOC overestimate, Bastin et al. did not account for the warming effect of trees due to decreased albedo $(3,4)$. Trees, particularly evergreen conifers, are less reflective than snow, bare ground, or grasses, and thus absorb more solar energy, which is ultimately emitted as heat. At high latitudes and elevations, the warming effect of trees is greater than their cooling effect via carbon sequestration (3, 4). Similarly, trees planted in low-latitude, semi-arid regions can produce net warming for decades before carbon sequestration benefits are realized (10). Because, at a minimum, carbon from trees planted in boreal forests, tundra, or montane grasslands and shrublands should not be counted as climate change mitigation (Bastin et al. counted a SOCcorrected $17 \mathrm{GtC}$ ), in Table 1 we provide a corrected estimate that excludes these biomes.

The carbon sequestration estimate of Bastin et al. is also dependent on the false assumption that natural grasslands and savannas with fewer trees than predicted by their statistical model are "degraded" and in need of restoration (11). Ecological restoration of savannas and grasslands rarely involves planting trees, and more often requires tree-cutting and prescribed fire to promote biodiversity and ecosystem services (12). Yet after correcting for SOC, $46 \%$ of the carbon sequestration estimate of Bastin et al. comes from increased tree cover in grasslands, savannas, and shrublands (Table 1). Among all biomes, tropical grasslands are the largest contributor to Bastin et al.'s estimate of potential carbon se- questration (SOC-corrected $40 \mathrm{GtC}$ or $37 \%$ of the global potential; Table 1).

Although Bastin et al.'s model, developed with climate and soil data in protected areas, may be reasonable in some of the driest and wettest places on Earth, any statistical approach to predict tree cover at intermediate precipitation (500 to $2500 \mathrm{~mm}$ annually) must include the effects of fire and, where they still exist, large grazing and browsing animals (13). Because Bastin et al. failed to account for fire, their model had low predictive power across many of the open-canopy biomes they analyzed, as shown by their own uncertainty analysis. Although we commend their intent to respect the "natural ecosystem type" by training their machine-learning algorithm on protected areas, they map many of these same areas-particularly those with grassland-forest mosaics (e.g., Yellowstone National Park, USA)as opportunities for tree planting. Of additional concern, their method of interpolation between protected areas misrepresents some enormous savanna regions (e.g., western Los Llanos in Colombia is targeted for 75 to $100 \%$ tree cover), presumably because the protected areas are located in adjacent tropical forests, not savannas.

Bastin et al.'s model suggesting grasslands and savannas as potential sites for restoration using trees is inaccurate and misguided. Earth's savannas and grasslands predate humans by millions of years; their formation is a result of complex ecological and evolutionary interactions among herbaceous plants (grasses and forbs with extensive roots and underground storage organs), environmental change (climatic cooling, drying, changes in atmospheric $\mathrm{CO}_{2}$ ), fires (first ignited by lightning, then by people), and large herbivores $(5,6)$. These ecosystems and their iconic species are already gravely threatened by fire exclusion and afforestation, processes that replace species-diverse biotic communities with lower-diversity forests (14). Carbon-focused tree planting will exacerbate these threats, to the detriment of people who depend on grasslands to provide livestock forage, game habitat, and groundwater and surface-water recharge (11). Moreover, trees planted in grasslands will be prone to carbon loss from fires. Because these detrimental effects should preclude tree planting in grasslands, savannas, and shrublands, we excluded these biomes from Bastin et al.'s estimate in Table 1.

In combination, our corrections for SOC and corrections to avoid the unintended consequences of misguided tree planting (i.e., warming and biodiversity loss with afforestation) would reduce Bastin et al.'s estimate of potential carbon sequestration by a factor of 5, to the still-substantial amount of $\sim 42 \mathrm{GtC}$ (Table 1). Although ecological restoration, if carefully implemented, can have a role in mitigating climate change, it is no substitute for the fact that most fossil fuel emissions will need to stop to meet the targets of the 
Paris Agreement (15). Such action should be accompanied by policies that prioritize the conservation of intact, biodiverse ecosystems, irrespective of whether they contain a lot of trees.

\section{REFERENCES}

1. J. F. Bastin, Y. Finegold, C. Garcia, D. Mollicone, M. Rezende, D. Routh, C. M. Zohner, T. W. Crowther, The global tree restoration potential. Science 365, 7679 (2019). doi:10.1126/science.aax0848 Medline

2. C. Le Quéré, R. M. Andrew, P. Friedlingstein, S. Sitch, J. Hauck, J. Pongratz, P. A. Pickers, J. I. Korsbakken, G. P. Peters, J. G. Canadell, A. Arneth, V. K. Arora, L. Barbero, A. Bastos, L. Bopp, F. Chevallier, L. P. Chini, P. Ciais, S. C. Doney, T. Gkritzalis, D. S. Goll, I. Harris, V. Haverd, F. M. Hoffman, M. Hoppema, R. A. Houghton, G. Hurtt, T. Ilyina, A. K. Jain, T. Johannessen, C. D. Jones, E. Kato, R. F. Keeling, K. K. Goldewijk, P. Landschützer, N. Lefèvre, S. Lienert, Z. Liu, D. Lombardozzi, N. Metzl, D. R. Munro, J. E. M. S. Nabel, S. Nakaoka, C. Neill, A. Olsen, T. Ono, P. Patra, A. Peregon, W. Peters, P. Peylin, B. Pfeil, D. Pierrot, B. Poulter, G. Rehder, L. Resplandy, E. Robertson, M. Rocher, C. Rödenbeck, U. Schuster, J. Schwinger, R. Séférian, I. Skjelvan, T. Steinhoff, A. Sutton, P. P. Tans, H. Tian, B. Tilbrook, F. N. Tubiello, I. T. van der Laan-Luijkx, G. R. van der Werf, N. Viovy, A. P. Walker, A. J. Wiltshire, R. Wright, S. Zaehle, B. Zheng, Global carbon budget 2018. Earth Syst. Sci. Data 10, 2141-2194 (2018). doi:10.5194/essd-10-2141-2018

3. Y. Li, M. Zhao, S. Motesharrei, Q. Mu, E. Kalnay, S. Li, Local cooling and warming effects of forests based on satellite observations. Nat. Commun. 6, 6603 (2015). doi:10.1038/ncomms7603 Medline

4. P. M. Mykleby, P. K. Snyder, T. E. Twine, Quantifying the trade-off between carbon sequestration and albedo in midlatitude and high-latitude North American forests. Geophys. Res. Lett. 44, 2493-2501 (2017). doi:10.1002/2016GL071459

5. C. A. E. Strömberg, Evolution of grasses and grassland ecosystems. Annu. Rev. Earth Planet. Sci. 39, 517-544 (2011). doi:10.1146/annurev-earth-040809$\underline{152402}$

6. J. W. Veldman, E. Buisson, G. Durigan, G. W. Fernandes, S. Le Stradic, G. Mahy, D. Negreiros, G. E. Overbeck, R. G. Veldman, N. P. Zaloumis, F. E. Putz, W. J. Bond, Toward an old-growth concept for grasslands, savannas, and woodlands. Front Ecol. Environ. 13, 154-162 (2015). doi:10.1890/140270

7. J. Grace, J. S. José, P. Meir, H. S. Miranda, R. A. Montes, Productivity and carbon fluxes of tropical savannas. J. Biogeogr. 33, 387-400 (2006). doi:10.1111/j.13652699.2005.01448.x

8. Y. Pan, R. A. Birdsey, J. Fang, R. Houghton, P. E. Kauppi, W. A. Kurz, O. L. Phillips, A. Shvidenko, S. L. Lewis, J. G. Canadell, P. Ciais, R. B. Jackson, S. W. Pacala, A. D. McGuire, S. Piao, A. Rautiainen, S. Sitch, D. Hayes, A large and persistent carbon sink in the world's forests. Science 333, 988-993 (2011). doi:10.1126/science.1201609 Medline

9. R. B. Jackson, J. L. Banner, E. G. Jobbágy, W. T. Pockman, D. H. Wall, Ecosystem carbon loss with woody plant invasion of grasslands. Nature 418, 623-626 (2002). doi:10.1038/nature00910 Medline

10. E. Rotenberg, D. Yakir, Contribution of semi-arid forests to the climate system. Science 327, 451-454 (2010). doi:10.1126/science.1179998 Medline

11. J. W. Veldman, G. E. Overbeck, D. Negreiros, G. Mahy, S. Le Stradic, G. W. Fernandes, G. Durigan, E. Buisson, F. E. Putz, W. J. Bond, Where tree planting and forest expansion are bad for biodiversity and ecosystem services. Bioscience 65, 1011-1018 (2015). doi:10.1093/biosci/biv118

12. E. Buisson, S. Le Stradic, F. A. O. Silveira, G. Durigan, G. E. Overbeck, A. Fidelis, G. W. Fernandes, W. J. Bond, J.-M. Hermann, G. Mahy, S. T. Alvarado, N. P. Zaloumis, J. W. Veldman, Resilience and restoration of tropical and subtropical grasslands, savannas, and grassy woodlands. Biol. Rev. Camb. Philos. Soc. 94 , 590-609 (2019). doi:10.1111/brv.12470 Medline

13. A. C. Staver, S. Archibald, S. A. Levin, The global extent and determinants of savanna and forest as alternative biome states. Science 334, 230-232 (2011). doi:10.1126/science.1210465 Medline

14. R. C. R. Abreu, W. A. Hoffmann, H. L. Vasconcelos, N. A. Pilon, D. R. Rossatto, G. Durigan, The biodiversity cost of carbon sequestration in tropical savanna. Sci. Adv. 3, e1701284 (2017). doi:10.1126/sciadv.1701284 Medline

15. IPCC, Global Warming of $1.5^{\circ} \mathrm{C}$ : An IPCC Special Report on the Impacts of Global Warming of $1.5^{\circ} \mathrm{C}$ Above Pre-Industrial Levels and Related Global Greenhouse Gas Emission Pathways, in the Context of Strengthening the Global Response to the Threat of Climate Change, Sustainable Development, and Efforts to Eradicate Poverty, V. Masson-Delmotte et al., Eds. (World Meteorological Organization, Geneva, 2018).

16. O. V. Menyailo, B. A. Hungate, W. Zech, Tree species mediated soil chemical changes in a Siberian artificial afforestation experiment. Plant Soil 242, 171-182 (2002). doi:10.1023/A:1016290802518

17. A. Don, J. Schumacher, A. Freibauer, Impact of tropical land-use change on soil organic carbon stocks-a meta-analysis. Glob. Change Biol. 17, 1658-1670 (2011). doi:10.1111/j.1365-2486.2010.02336.x

18. C. Poeplau, A. Don, L. Vesterdal, J. Leifeld, B. Van Wesemael, J. Schumacher, A. Gensior, Temporal dynamics of soil organic carbon after land-use change in the temperate zone-carbon response functions as a model approach. Glob. Change Biol. 17, 2415-2427 (2011). doi:10.1111/j.1365-2486.2011.02408.x

19. K. Makoto, S. V. Bryanin, V. V. Lisovsky, K. Kushida, N. Wada, Dwarf pine invasion in an alpine tundra of discontinuous permafrost area: Effects on fine root and soil carbon dynamics. Trees 30, 431-439 (2016). doi:10.1007/s00468-015-1192-5

20. J. P. Zhang, C. D. Shen, H. Ren, J. Wang, W. D. Han, Estimating change in sedimentary organic carbon content during mangrove restoration in southern China using carbon isotopic measurements. Pedosphere 22, 58-66 (2012) doi:10.1016/S1002-0160(11)60191-4

21. M. Hoogmoed, S. C. Cunningham, J. R. Thomson, P. J. Baker, J. Beringer, T. R. Cavagnaro, Does afforestation of pastures increase sequestration of soil carbon in Mediterranean climates? Agric. Ecosyst. Environ. 159, 176-183 (2012). doi:10.1016/j.agee.2012.07.011

\section{ACKNOWLEDGMENTS}

J.W.V. thanks B. J. Danielson for many conversations on related topics. Funding: Supported by the Texas A\&M Sid Kyle Global Savanna Research Initiative (T.W.B.); Swiss National Science Foundation (20FI20_173691) (N.B.); Centre National pour la Recherche Scientifique CNRS PICS 2018-2020 (RESIGRASS) (E.B.); CNPq (Brazil, 303179/2016-3) (G.D.); CNPq (Brazil) (G.W.F.); CNPq (Brazil, 303988/2018-5) (A.F.); NASA award NNX17AK14G (F.F.); NSF award 1354943 (W.A.H.); Fundação de Amparo à Pesquisa do Estado de Minas Gerais (Brazil, 2016/13232-5) (S.L.S.); the Office of the Royal Society (IC170015) (C.E.R.L.); CNPq (Brazil, 310345/2018-9) (G.E.O.); the Spanish Government (FIROTIC, PGC2018-096569-B-I00) (J.G.P.); the National Research Foundation (ACCESS, 114695) (N.S.); CNPq (Brazil, 303568/2017-8) (F.A.O.S.); NSF awards 1342703 and 1926431 (C.J.S. and D.M.G.); NSF award EAR-1253713 (C.A.E.S.); Deutsche Forschungsgemeinschaft grant 5579 POEM (V.M.T.); and USDA-NIFA Sustainable Agricultural Systems Grant 12726253 (J.W.V.). Author contributions: J.W.V. wrote the paper with conceptual input from C.L.P., S.A., C.J.S., G.M., W.J.B., J.J.E., and V.M.T.; J.W.V. performed the carbon sequestration corrections in Table 1; J.G.P. and A.N.N. contributed to the literature search for $\triangle S O C$ values. All authors read and provided feedback on the draft manuscript. Competing interests: The authors declare that they have no competing interests. Data and materials availability: All data, explanations of calculations, and references to literature-derived values are presented in Table 1.

19 July 2019; accepted 27 September 2019

Published online 18 October 2019

10.1126/science.aay7976 
Table 1. Corrected estimates of the potential for increased tree cover to sequester carbon and mitigate climate change. We corrected Bastin et al.'s estimate (205 GtC) to represent realistic gains or losses of soil organic carbon (SOC) that occur with increased tree cover in each biome [based on $(9,16-21)]$. We then excluded biomes (assigned a value of $0 \mathrm{GtC}$ ) where tree planting for climate change mitigation should not occur because of unintended consequences (e.g., net warming from reduced albedo or loss of biodiversity). Although we disagrê.e with several of the carbon density values used by Bastin et al. [e.g., they applied values for intact tropical forests (8) to estimate second-grovith forest biomass, and applied values from humid tropical savannas (7) to deserts and tundra], we retained these values to demonstrate the maggitude of the SOC and biome corrections.

\begin{tabular}{|c|c|c|c|c|c|c|c|c|c|c|c|}
\hline Biome* & $\begin{array}{l}\text { Canopy cover } \\
\text { restoration area } \\
(\mathrm{Mha})^{*}\end{array}$ & $\begin{array}{c}\text { Carbon } \\
\text { density } \\
(\mathrm{tC} / \mathrm{ha})^{*}\end{array}$ & \multicolumn{2}{|c|}{ Potential carbon stocks, Bastin et al. ( ()} & $\begin{array}{c}\Delta \mathrm{C} \text { biomass } \\
(\mathrm{tC} / \mathrm{ha}) \dagger\end{array}$ & $\begin{array}{c}\Delta S O C \\
(t C / h a) \dagger\end{array}$ & $\begin{array}{c}\text { Realistic } \\
\triangle \mathrm{SOC} \\
\text { (tC/ha) }\end{array}$ & $\begin{array}{c}\text { Realistic } \\
\triangle S O C \\
\text { source }\end{array}$ & $\begin{array}{l}\text { SOC-corrected } \\
\text { carbon gain } \\
\text { (GtC) }\end{array}$ & \multicolumn{2}{|c|}{ 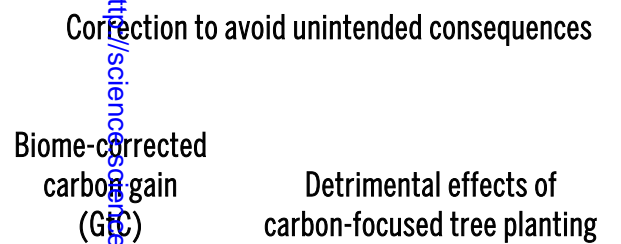 } \\
\hline Boreal forests/taiga & 178 & 239 & $(8)$ & 42.6 & 85 & 154 & 0 & $(16) \ddagger$ & 15.2 & 覀 & $\downarrow$ albedo (net warming) \\
\hline Deserts and xeric shrublands & 78 & 202 & $(7)$ & 15.7 & 28 & 174 & 5.1 & $(9) \S$ & 2.6 & $\stackrel{Q}{\Phi}$ & $\downarrow$ provisioning of water, $\uparrow$ fire intensity \\
\hline Flooded grasslands andsavannas & 9 & 202 & $(7)$ & 1.8 & 28 & 174 & 12.4 & $(17)$ & 0.4 & 5 & $\downarrow$ biodiversity \\
\hline Montane grasslands and shrublands & 19 & 202 & $(7)$ & 3.9 & 28 & 174 & -3.3 & (18) & 0.5 & $\bar{\phi}$ & $\downarrow$ biodiversity, $\downarrow$ albedo (net warming) \\
\hline Temperate grasslands & 73 & 155 & (8) & 11.2 & 81 & 74 & -3.3 & (18) & 5.6 & $\begin{array}{l}\vec{\Phi} \\
\stackrel{\mathbb{N}}{\mathbb{N}} \\
\overrightarrow{\vec{T}}\end{array}$ & $\begin{array}{l}\downarrow \text { biodiversity, } \downarrow \text { forage production, } \\
\uparrow \text { fire severity }\end{array}$ \\
\hline Tropical grasslands & 190 & 283 & (8) & 53.5 & 199 & 84 & 12.4 & (17) & 40.0 & $\underset{O}{Q}$ & $\begin{array}{l}\downarrow \text { biodiversity, } \downarrow \text { provisioning of water, } \\
\downarrow \text { forage production, } \uparrow \text { fire severity }\end{array}$ \\
\hline Tundra & 51 & 202 & (7) & 10.2 & 28 & 174 & 0 & $(19) \ddagger$ & 1.4 & 0 & $\downarrow$ albedo (net warming) \\
\hline Mangroves & 3 & 283 & (8) & 0.7 & 199 & 84 & 198 & (20) & 1.0 & 1.0 & \\
\hline Mediterranean forests & 19 & 202 & (7) & 3.8 & 28 & 174 & 0 & $(21) \ddagger$ & 0.5 & 0.5 & $\uparrow$ fire intensity\# \\
\hline Temperate broadleaf & 109 & 155 & (8) & 16.9 & 81 & 74 & -3.3 & (18) & 8.4 & 8.4 & \\
\hline Temperate conifer forests & 36 & 155 & (8) & 5.6 & 81 & 74 & -3.3 & (18) & 2.8 & 2.8 & $\uparrow$ fire intensity and severity, $\downarrow$ albedo\# \\
\hline Tropical coniferous forests & 7 & 283 & (8) & 2.0 & 199 & 84 & 12.4 & $(17)$ & 1.5 & 1.5 & \\
\hline Tropical dry broadleaf forests & 33 & 283 & (8) & 9.3 & 199 & 84 & 12.4 & $(17)$ & 6.9 & 6.9 & \\
\hline Tropical moist broadleaf forests & 97 & 283 & (8) & 27.4 & 199 & 84 & 12.4 & $(17)$ & 20.5 & 20.5 & \\
\hline Total & 900 & & & 205 & & & & & 107 & 42 & \\
\hline
\end{tabular}

*From materials and methods and table S2 of Bastin et al. (1): Carbon gain = canopy cover restoration area $\times$ carbon density.

†Portion of carbon density attributable to biomass and soil, from the same sources used by Bastin et al. [i.e., $(7,8)]$.

$¥$ Studies that report no statistically significant change in SOC.

$\S$ Mean of two sites with annual precipitation $<300 \mathrm{~mm}$.

ISOC-corrected carbon gain = canopy cover restoration area $\times(\triangle \mathrm{C}$ biomass + realistic $\triangle \mathrm{SOC})$.

\#Strength of effects depends on ecological context, but effects are not universal enough to exclude the biome. 


\section{Science}

\section{Comment on "The global tree restoration potential"}

Joseph W. Veldman, Julie C. Aleman, Swanni T. Alvarado, T. Michael Anderson, Sally Archibald, William J. Bond, Thomas W. Boutton, Nina Buchmann, Elise Buisson, Josep G. Canadell, Michele de Sá Dechoum, Milton H. Diaz-Toribio, Giselda Durigan, John J. Ewel, G. Wilson Fernandes, Alessandra Fidelis, Forrest Fleischman, Stephen P. Good, Daniel M. Griffith, Julia-Maria

Hermann, William A. Hoffmann, Soizig Le Stradic, Caroline E. R. Lehmann, Gregory Mahy, Ashish N. Nerlekar, Jesse B. Nippert, Reed F. Noss, Colin P. Osborne, Gerhard E. Overbeck, Catherine L. Parr, Juli G. Pausas, R. Toby Pennington, Michael P. Perring, Francis E. Putz, Jayashree Ratnam, Mahesh Sankaran, Isabel B. Schmidt, Christine B. Schmitt, Fernando A. O. Silveira, A. Carla Staver, Nicola Stevens, Christopher J. Still, Caroline A. E. Strömberg, Vicky M. Temperton, J. Morgan Varner and Nicholas P. Zaloumis

Science 366 (6463), eaay7976.

DOI: $10.1126 /$ science.aay 7976

ARTICLE TOOLS

RELATED
CONTENT

REFERENCES

PERMISSIONS http://science.sciencemag.org/content/366/6463/eaay7976

http://science.sciencemag.org/content/sci/366/6463/eaay8060.full http://science.sciencemag.org/content/sci/365/6448/76.full http://science.sciencemag.org/content/sci/366/6463/eaay8108.full http://science.sciencemag.org/content/sci/366/6463/eaaz0388.full http://science.sciencemag.org/content/sci/366/6463/eaay8334.full

This article cites 20 articles, 5 of which you can access for free http://science.sciencemag.org/content/366/6463/eaay7976\#BIBL

http://www.sciencemag.org/help/reprints-and-permissions

Use of this article is subject to the Terms of Service

Science (print ISSN 0036-8075; online ISSN 1095-9203) is published by the American Association for the Advancement of Science, 1200 New York Avenue NW, Washington, DC 20005. The title Science is a registered trademark of AAAS.

Copyright (C) 2019 The Authors, some rights reserved; exclusive licensee American Association for the Advancement of Science. No claim to original U.S. Government Works 


\title{
Comment on "The global tree restoration potential"
}

\author{
Simon L. Lewis ${ }^{1,2 *}$, Edward T. A. Mitchard ${ }^{3}$, Colin Prentice ${ }^{4}$, Mark Maslin ${ }^{1}$, Ben Poulter ${ }^{5}$ \\ ${ }^{1}$ Department of Geography, University College London, London WC1E 6BT, UK. ² School of Geography, University of Leeds, Leeds LS2 9JT, UK. ${ }^{3}$ School of \\ GeoSciences, University of Edinburgh, Edinburgh EH9 3FF, UK. ${ }^{4}$ Department of Life Science, Imperial College, Ascot, Berks SL5 7PY, UK. ${ }^{5}$ NASA Goddard Space \\ Flight Center, Greenbelt, MD, USA.
}

${ }^{*}$ Corresponding author. Email: s.l.lewis@leeds.ac.uk

Bastin et al. (Reports, 5 July 2019, p. 76) state that the restoration potential of new forests globally is 205 gigatonnes of carbon, conclude that "global tree restoration is our most effective climate change solution to date," and state that climate change will drive the loss of $\mathbf{4 5 0}$ million hectares of existing tropical forest by 2050 . Here we show that these three statements are incorrect.

Bastin et al. (1) provide an assessment of the potential to expand the area of Earth allocated to forests to sequester carbon to mitigate climate change. They (i) produce a datadriven model to estimate the potential area of Earth where trees will grow, then exclude existing forest, croplands, and urban areas, estimating that the remaining 900 Mha of new tree cover is the global "restoration potential"; (ii) estimate that the resulting carbon sequestration from foresting this area is $205 \mathrm{GtC}$; (iii) suggest that this will offset two-thirds of the "global anthropogenic carbon burden," making it the "most effective climate change solution to date"; and finally (iv) extend their spatial model of restoration potential in time, showing a net 223 Mha decrease in global tree cover by 2050 . We consider the last three of these results to be fundamentally flawed.

The stated $205 \mathrm{GtC}$ restoration potential is $0.22 \mathrm{GtC}$ $\mathrm{Mha}^{-1}$ new forest cover, double previously published estimates (2-5). This anomaly is not noted by the authors (1). Four alternative approaches show that this number is almost certainly too high:

1) Anthropogenic land-use change, since 1750 , has emitted $200 \mathrm{GtC}$, which suggests that it is highly unlikely that restoring only a fraction of previously deforested land will itself sequester $205 \mathrm{GtC}$ (5). The $900 \mathrm{Mha}$ that Bastin et al. suggest restoring is $39 \%$ of formerly tree-covered land (1), hence historical evidence suggests that restoring this proportion of it would lead to $78 \mathrm{GtC}$ uptake. Add the fraction of the $200 \mathrm{GtC}$ land sink since 1750 attributable to the 900 Mha ( $14 \%$ of once tree-covered land and today's existing forests), and from first principles we expect $107 \mathrm{GtC}$ uptake from restoring 900 Mha of new tree cover $\left(0.12 \mathrm{GtC} \mathrm{Mha}^{-1}\right)$.

2) Using a fully coupled climate model to restore $100 \%$ of agricultural land (2) predicts 240 GtC uptake on 2020 Mha of land (0.12 GtC $\left.\mathrm{Mha}^{-1}\right)$. This converts to $107 \mathrm{GtC}$ for restoring 900 Mha.

3) Using mapped restoration areas regenerating to climatically supportable carbon stock levels (3) results in 108 GtC sequestered over 900 Mha (0.12 GtC $\left.\mathrm{Mha}^{-1}\right)$.

4) A mapping exercise that identified restoration areas, with no economic constraints and published sequestration rates, gave a median estimate of $89 \mathrm{GtC}$ when scaled to 900 Mha (4) (0.10 GtC Mha ${ }^{-1}$.

Although Bastin et al. use tree cover area as their metric, this is directly comparable to the above land area estimates, because their methods account for this; for example, $10 \%$ tree cover is only $10 \%$ of the per-hectare carbon sequestration. The four published estimates above are similar, with a mean of $103 \mathrm{GtC}$ (range, 89 to 108), just 50\% the Bastin et al. estimate.

Bastin et al.'s anomalous result arises because their multiplication of tree cover area by mature ecosystem carbon stock levels is incorrect. First, they assume, incorrectly, that soil carbon stocks are zero prior to restoration. The original carbon density values used in (1) show that 37 to $86 \%$ of the carbon sequestration in each vegetation class is new soil carbon, a total of $113 \mathrm{GtC}$. This is not credible: It is equivalent to all the soil organic carbon lost globally since the advent of farming, 116 GtC (6). Critically, when converting grassland or pasture to tree-covered land [the majority of the new tree cover (1)], meta-analyses show no overall trend in soil carbon stocks $(7,8)$. Alternatively, if the global average $3.6 \%$ loss of soil organic carbon was assumed to return to these soils, that would add $4 \mathrm{GtC}$, not $113 \mathrm{GtC}$ as Bastin et al. claim. Thus, the total sequestration, when accounting for the prior existence of carbon in soil, is $\sim 96 \mathrm{GtC}$, in line with published estimates.

Bastin et al. secondly assume that live stem, leaf, root, and necromass are all also zero prior to restoration. This is 
not correct: All of the 900 Mha they highlight as available has plants growing on it, and a substantial proportion will have some trees already. Carbon removed from the atmosphere by restoration is only that added to the system from new additional vegetation growth. To illustrate the likely magnitude of this error, a recent restoration potential analysis showed $42.1 \mathrm{GtC}$ uptake from restoring 350 Mha of forest, in addition to the 10.6 GtC already in biomass on the land prior to restoration (3). Using the Bastin et al. method, sequestration would thus have been overreported by $\sim 25 \%$.

The third Bastin et al. assumption is that future environmental change will have no impact on forest carbon stocks. Typically, higher atmospheric $\mathrm{CO}_{2}$ concentrations increase carbon stocks more than higher temperatures and altered rainfall reduce it $(9,10)$. Given the intrinsic uncertainty of future emissions, this impact could be as low as $\sim 7 \%$ under a low-emission scenario (3), or as high as a $\sim 20 \%$ increase under a mid-range scenario for the tropical forest biome (11). Assuming the latter and taking all three biases into account (initial soil, initial biomass, changing environment), $~ 92 \mathrm{GtC}$ is expected to be sequestered in 900 Mha of new forest cover (92 GtC on the land after restoration, minus $23 \mathrm{GtC}$ already on the land, plus $4 \mathrm{GtC}$ added to the soil, plus 19 GtC added from the changing environment). This corrected $92 \mathrm{GtC}$ value is similar to the four independent sequestration estimates detailed above, but is less than half the Bastin et al. estimate.

The authors then compound their overestimate of the importance of forest restoration by asserting that "reaching this maximum restoration potential $[205 \mathrm{GtC}]$ would reduce a considerable proportion of the global anthropogenic carbon burden $(\sim 300 \mathrm{GtC})$ to date." This $67 \%$ reduction is not correct. Human actions have added 640 GtC since 1750; thus, $205 / 640$ is $32 \%$. The authors appear to have confused the increase in atmospheric carbon dioxide concentration since 1750 with total anthropogenic emissions. The difference is because $\sim 55 \%$ of anthropogenic $\mathrm{CO}_{2}$ emissions were removed from the atmosphere into land and ocean sinks. Reversing the atmospheric increase via restoration concomitantly weakens the sink strength $(2,5,12)$. Thus, overall, restoration over 900 Mha is $\sim 100 \mathrm{GtC}$, which would reduce the anthropogenic burden by $\sim 15 \%$ [i.e., $(100 \times 0.45) / 300$ from an atmospheric perspective, or 100/640 from an emissions perspective), not $\sim 67 \%$ as Bastin et al. claim. Furthermore, $15 \%$ overestimates the climate impact of Bastin et al.'s restoration potential, because $25 \%$ of the new tree cover is in tundra and boreal regions, where warming from forests' lower surface albedo can offset the cooling from new carbon uptake (13).

Bastin et al. state in their abstract that "[our study] highlights global tree restoration as our most effective climate change solution to date." This statement is not sup- ported by the evidence provided. Furthermore, such a statement can never be supported because (i) in physical terms, keeping fossil carbon in its original geological storage is self-evidently a more effective solution to climate change than releasing it and capturing it later in trees; (ii) allowing trees to grow where they once grew is largely merely replacing carbon that was previously lost through land-use change, and so does not address fossil fuel emissions; and (iii) sequestering $\sim 100 \mathrm{GtC}$ into new forests is equivalent to just 10 years of current emissions, which clearly shows that forest restoration is of lower importance than rapidly reducing fossil fuel emissions.

Finally, Bastin et al. model the future, concluding that "global potential canopy cover may shrink by $\sim 223$ million hectares by 2050 , with the vast majority of losses occurring in the tropics." The authors state that their results are "in stark contrast to most current model predictions" but give no explanation for this. The reason is that they first parameterize an environment-tree cover association in space for the recent past, and then apply it over time into the future, giving an erroneous result. This arises because there are no current areas of Earth today that are as hot as will exist in the core wet tropics in 2050 . Thus, when 2050 climate output shows higher temperatures in areas of current tropical forest, the Bastin et al. machine-learning model fills in the tree cover from areas with the closest match from todaybut these are open forest and savanna areas that are also considerably drier than climate models predict for future tropical forest areas. This upper temperature limit problem is a well-recognized error within bioclimatic envelope-type modeling (14). Thus, although the intact Amazon carbon sink is declining, there is no hint of a decline in canopy cover (15) and a switch due to climate change alone, in the absence of deforestation and logging (which were not modeled), to swathes of open forest within the next 30 years is highly unlikely, even under the most pessimistic of climate-driven vegetation models (11).

One further contributory reason why the 2050 results that Bastin et al. report are in "stark contrast" to other models is because their spatial correlations exclude any impact of rising atmospheric $\mathrm{CO}_{2}$. Given that no place on Earth today has 2050-level $\mathrm{CO}_{2}$ concentrations, their machinelearning approach is not an appropriate approach. Tropical forests' response to global change is the net of a negative impact of high temperatures, a positive impact of rising $\mathrm{CO}_{2}$, and the impacts of any changes in rainfall or its distribution (9). The pivotal role of $\mathrm{CO}_{2}$ for photosynthesis is well known, evidenced from theory, observations, and experiments (9). The decision to ignore this evidence means that the reported net $46 \mathrm{GtC}$ loss from forest cover by 2050 is also incorrect. 


\section{REFERENCES}

1. J.-F. Bastin, Y. Finegold, C. Garcia, D. Mollicone, M. Rezende, D. Routh, C. M. Zohner, T. W. Crowther, The global tree restoration potential. Science 365, 7679 (2019). doi:10.1126/science.aax0848 Medline

2. V. K. Arora, A. Montenegro, Small temperature benefits provided by realistic afforestation efforts. Nat. Geosci. 4, 514-518 (2011). doi:10.1038/ngeo1182

3. S. L. Lewis, C. E. Wheeler, E. T. A. Mitchard, A. Koch, Restoring natural forests is the best way to remove atmospheric carbon. Nature 568, 25-28 (2019). doi:10.1038/d41586-019-01026-8 Medline

4. B. W. Griscom, J. Adams, P. W. Ellis, R. A. Houghton, G. Lomax, D. A. Miteva, W. H. Schlesinger, D. Shoch, J. V. Siikamäki, P. Smith, P. Woodbury, C. Zganjar, A. Blackman, J. Campari, R. T. Conant, C. Delgado, P. Elias, T. Gopalakrishna, M. R. Hamsik, M. Herrero, J. Kiesecker, E. Landis, L. Laestadius, S. M. Leavitt, S. Minnemeyer, S. Polasky, P. Potapov, F. E. Putz, J. Sanderman, M. Silvius, E. Wollenberg, J. Fargione, Natural climate solutions. Proc. Natl. Acad. Sci. U.S.A. 114, 11645-11650 (2017). doi:10.1073/pnas.1710465114 Medline

5. J. I. House, I. C. Prentice, C. Le Quéré, Maximum impacts of future reforestation or deforestation on atmospheric $\mathrm{CO}_{2}$. Glob. Change Biol. 8, 1047-1052 (2002). doi:10.1046/j.1365-2486.2002.00536.x

6. J. Sanderman, T. Hengl, G. J. Fiske, Soil carbon debt of 12,000 years of human land use. Proc. Natl. Acad. Sci. U.S.A. 114, 9575-9580 (2017). doi:10.1073/pnas.1706103114 Medline

7. L. B. Guo, R. M. Gifford, Soil carbon stocks and land use change: A meta analysis. Glob. Change Biol. 8, 345-360 (2002). doi:10.1046/j.1354-1013.2002.00486.x

8. L. Deng, G.-y. Zhu, Z. Tang, Z. Shangguan, Global patterns of the effects of landuse changes on soil carbon stocks. Glob. Ecol. Conserv. 5, 127-138 (2016). doi:10.1016/j.gecco.2015.12.004

9. P. Ciais et al., in Climate Change 2013: The Physical Science Basis. Contribution of Working Group I to the Fifth Assessment Report of the Intergovernmental Panel on Climate Change, T. F. Stocker et al., Eds. (Cambridge Univ. Press, 2014).

10. S. L. Lewis, D. P. Edwards, D. Galbraith, Increasing human dominance of tropical forests. Science 349, 827-832 (2015). doi:10.1126/science.aaa9932 Medline

11. C. Huntingford, P. Zelazowski, D. Galbraith, L. M. Mercado, S. Sitch, R. Fisher, M. Lomas, A. P. Walker, C. D. Jones, B. B. B. Booth, Y. Malhi, D. Hemming, G. Kay, P. Good, S. L. Lewis, O. L. Phillips, O. K. Atkin, J. Lloyd, E. Gloor, J. ZaragozaCastells, P. Meir, R. Betts, P. P. Harris, C. Nobre, J. Marengo, P. M. Cox, Simulated resilience of tropical rainforests to $\mathrm{CO}_{2}$-induced climate change. Nat. Geosci. 6, 268-273 (2013). doi:10.1038/ngeo1741

12. C. D. Jones, P. Ciais, S. J. Davis, P. Friedlingstein, T. Gasser, G. P. Peters, J. Rogelj, D. P. van Vuuren, J. G. Canadell, A. Cowie, R. B. Jackson, M. Jonas, E. Kriegler, E. Littleton, J. A. Lowe, J. Milne, G. Shrestha, P. Smith, A. Torvanger, A. Wiltshire, Simulating the Earth system response to negative emissions. Environ. Res. Lett. 11, 095012 (2016). doi:10.1088/1748-9326/11/9/095012

13. R. A. Betts, Offset of the potential carbon sink from boreal forestation by decreases in surface albedo. Nature 408, 187-190 (2000). doi:10.1038/35041545 Medline

14. K. J. Feeley, M. R. Silman, Biotic attrition from tropical forests correcting for truncated temperature niches. Glob. Change Biol. 16, 1830-1836 (2010). doi:10.1111/j.1365-2486.2009.02085.x

15. R. J. W. Brienen, O. L. Phillips, T. R. Feldpausch, E. Gloor, T. R. Baker, J. Lloyd, G. Lopez-Gonzalez, A. Monteagudo-Mendoza, Y. Malhi, S. L. Lewis, R. Vásquez Martinez, M. Alexiades, E. Álvarez Dávila, P. Alvarez-Loayza, A. Andrade, L. E. O. C. Aragão, A. Araujo-Murakami, E. J. M. M. Arets, L. Arroyo, G. A. Aymard C, O. S. Bánki, C. Baraloto, J. Barroso, D. Bonal, R. G. A. Boot, J. L. C. Camargo, C. V. Castilho, V. Chama, K. J. Chao, J. Chave, J. A. Comiskey, F. Cornejo Valverde, L. da Costa, E. A. de Oliveira, A. Di Fiore, T. L. Erwin, S. Fauset, M. Forsthofer, D. R. Galbraith, E. S. Grahame, N. Groot, B. Hérault, N. Higuchi, E. N. Honorio Coronado, H. Keeling, T. J. Killeen, W. F. Laurance, S. Laurance, J. Licona, W. E. Magnussen, B. S. Marimon, B. H. Marimon-Junior, C. Mendoza, D. A. Neill, E. M. Nogueira, P. Núñez, N. C. Pallqui Camacho, A. Parada, G. Pardo-Molina, J.

Peacock, M. Peña-Claros, G. C. Pickavance, N. C. A. Pitman, L. Poorter, A. Prieto,
C. A. Quesada, F. Ramírez, H. Ramírez-Angulo, Z. Restrepo, A. Roopsind, A. Rudas, R. P. Salomão, M. Schwarz, N. Silva, J. E. Silva-Espejo, M. Silveira, J. Stropp, J. Talbot, H. ter Steege, J. Teran-Aguilar, J. Terborgh, R. Thomas-Caesar, M. Toledo, M. Torello-Raventos, R. K. Umetsu, G. M. F. van der Heijden, P. van der Hout, I. C. Guimarães Vieira, S. A. Vieira, E. Vilanova, V. A. Vos, R. J. Zagt, Longterm decline of the Amazon carbon sink. Nature 519, 344-348 (2015). doi:10.1038/nature14283 Medline

7 August 2019; accepted 27 September 2019

Published online 18 October 2019

10.1126/science.aaz0388 


\section{Science}

\section{Comment on "The global tree restoration potential"}

Simon L. Lewis, Edward T. A. Mitchard, Colin Prentice, Mark Maslin and Ben Poulter

Science 366 (6463), eaaz0388.

DOI: $10.1126 /$ science.aaz0388

\section{RELATED}

REFERENCES

PERMISSIONS http://science.sciencemag.org/content/sci/366/6463/eaay8060.full http://science.sciencemag.org/content/sci/366/6463/eaay 7976 .full http://science.sciencemag.org/content/sci/365/6448/76.full http://science.sciencemag.org/content/sci/366/6463/eaay8108.full http://science.sciencemag.org/content/sci/366/6463/eaay8334.full

This article cites 14 articles, 4 of which you can access for free http://science.sciencemag.org/content/366/6463/eaaz0388\#BIBL

http://www.sciencemag.org/help/reprints-and-permissions

Use of this article is subject to the Terms of Service

Science (print ISSN 0036-8075; online ISSN 1095-9203) is published by the American Association for the Advancement of Science, 1200 New York Avenue NW, Washington, DC 20005. The title Science is a registered trademark of AAAS.

Copyright (C) 2019 The Authors, some rights reserved; exclusive licensee American Association for the Advancement of Science. No claim to original U.S. Government Works 


\title{
Comment on "The global tree restoration potential"
}

\author{
Alan Grainger ${ }^{1 *}$, Louis R. Iverson ${ }^{2}$, Gregg H. Marland ${ }^{3}$, Anantha Prasad ${ }^{2}$ \\ ${ }^{1}$ School of Geography, University of Leeds, Leeds LS2 9JT, UK. ' U.S. Forest Service, Northern Research Station and Northern Institute of Applied Climate \\ Science, Delaware, OH 43015, USA. ${ }^{3}$ Department of Geological and Environmental Sciences, Appalachian State University, Boone, NC 28608, USA. \\ *Corresponding author. Email: a.grainger@leeds.ac.uk
}

Bastin et al. (Reports, 5 July 2019, p. 76) neglect considerable research into forest-based climate change mitigation during the 1980 s and 1990s. This research supports some of their findings on the area of land technically suitable for expanding tree cover, and can be used to extend their analysis to include the area of actually available land and operational feasibility.

The paper by Bastin et al. (1) is to be welcomed for drawing fresh attention to the potential for expanding forest and tree cover to mitigate global climate change by sequestering $\mathrm{CO}_{2}$ from the atmosphere. Unfortunately, it fails to acknowledge the huge amount of research in this field during the 1980s and 1990s. This is a common problem because the UN Framework Convention on Climate Change did not begin negotiations on a REDD+ (Reducing Emissions from Deforestation and Degradation) mechanism until 2007, and research to support REDD+ has grown rapidly since then. As Bastin et al. emphasize, time is short. So it is vital that new forest mitigation programs build on preexisting knowledge and do not try to "reinvent the wheel." Here, we use key achievements of this early research to assess the contributions and limitations of Bastin et al.'s findings.

Bastin $e t a l$. find "room for an extra 0.9 billion hectares of canopy cover, which could store 205 gigatonnes of carbon" and relate this to the net amount of carbon transferred into the atmosphere since pre-industrial times. Early estimates, however, focused on the size of a new forest sink needed to sequester a meaningful amount of carbon on a continuing basis. They included (i) 500 Mha to absorb gross emissions in the 1980s of 5 gigatonnes of carbon per year $\left(\mathrm{GtC}_{\mathrm{year}}^{-1}\right)(2)$, and (ii) $465 \mathrm{Mha}$ with a growth rate of $15 \mathrm{~m}^{3}$ ha $^{-1}$ year $^{-1}$ to sequester only the net annual rise of $2.9 \mathrm{GtC}$ year $^{-1}$ in the atmosphere (3) after uptake by terrestrial and oceanic sinks.

Later studies showed that more than enough degraded tropical land existed to support forest expansion on this scale. Two papers presented to an Intergovernmental Panel on Climate Change (IPCC) conference in January 1990 estimated that in the tropics, (i) 620 Mha of degraded lands were physically suitable for establishing this new "carbonforest," and another 137 Mha of degraded forests could be restored (4); and (ii) 500 Mha of land could be afforested by
2100 , with a further 365 Mha of forest fallows having potential for restoration (5). Both studies were summarized in the First IPCC Assessment Report (6). The comparability of these findings with those of Bastin et al. is remarkable, given that Bastin et al. use very high ( $\leq 1 \mathrm{~m})$-resolution satellite data and cloud-based machine-learning algorithms, whereas early estimates depended largely on United Nations statistics-although one 1990 estimate did use low $(\geq 1 \mathrm{~km})$ resolution satellite data (5).

Bastin et al. also relate their principal finding to a recent IPCC estimate (7) that 950 Mha of new forests could help to "limit global warming to $1.5^{\circ} \mathrm{C}$ " by 2050 . Because this estimate is based on the current net annual rise in $\mathrm{CO}_{2}$ in the atmosphere, which is twice as high $\left(\sim 5.7 \mathrm{GtC}_{\text {year }}^{-1}\right)$ as in the $1980 \mathrm{~s}$, it is consistent with the 465 Mha considered appropriate 30 years ago (3).

Bastin et al. do not evaluate the operational feasibility of expanding tree cover in time to tackle global warming promptly. Nor does the recent IPCC report, which discusses planting 950 Mha of new forests in just 30 years (7). Yet one early study (4) argued that to afforest 600 Mha over a 30year period would require a planting rate 20 times the contemporary rate of 1 Mha year $^{-1}$. It anticipated REDD+ by showing that more modest planting rates could suffice if afforestation proceeded in parallel with programs to reduce the rate of tropical deforestation, which is a major source of carbon emissions (4).

Bastin et al. assess the potential to increase carbon density in existing forests, using carbon densities in protected areas as benchmarks, but do not mention a pioneering methodology for making restoration assessments that was devised in the early 1990s and applied to all of tropical Asia. Starting with an FAO map of tropical forest area in Asia in 1980 derived from medium-resolution Landsat satellite data, the distribution of potential forest carbon density was de- 
termined by using Geographical Information System modeling to combine forest inventory data (8) with multiple environmental datasets. Using degradation factors developed as a function of human population density for each ecofloristic zone along a moisture gradient, actual carbon density was then mapped to identify the distribution of degraded forests that could be restored. This map agreed well with an alternative map of a global vegetation index quantified using low-resolution satellite data $(9,10)$.

Commenting on Bastin et al.'s paper, Chazdon and Brancalion (11) wisely stress the need to address "social and environmental issues" in tree restoration. The importance of integrating afforestation with forest conservation was recognized in 1991 (12). Early studies also estimated the costs of afforestation; for example, just to plant a 300 Mha carbonforest over 30 years would cost US $\$ 4$ billion annually (4). These costs would be offset by income from converting the wood produced in the new forests into energy and harvested wood products (HWP), so these forests would be sustainable carbon sinks. The potential role of HWP in climate change mitigation is still poorly understood.

Increasingly sophisticated tools for feasibility analysis were then developed. The "technical suitability" of land for afforestation was distinguished from the "actual availability" of land on which afforestation might be socially, economically, and politically acceptable $(10,13)$, and the link between the level of national development (i.e., "developmental time") and the area of actually available land was recognized in the new concept of "national forest carbon transition functions" (14). Now that climate change is shifting the potential locations of biome boundaries (15), Bastin et al. rightly allow for the influence of "climatic time" on their assessment by including alternative climate change scenarios.

If Bastin et al.'s paper gives new impetus to using forests to mitigate climate change, then the results of this early research can finally be used for the purpose for which they were originally intended.

\section{REFERENCES}

1. J. F. Bastin, Y. Finegold, C. Garcia, D. Mollicone, M. Rezende, D. Routh, C. M. Zohner, T. W. Crowther, The global tree restoration potential. Science 365, 7679 (2019). doi:10.1126/science.aax0848 Medline

2. G. Marland, The Prospect of Solving the $\mathrm{CO}_{2}$ Problem Through Global Reforestation (U.S. Department of Energy, 1988).

3. R. A. Sedjo, A. M. Solomon, In Greenhouse Warming: Abatement and Adaptation (Resources for the Future, 1988), pp. 105-120.

4. A. Grainger, In Proceedings of the IPCC Conference on Tropical Forestry Response Options to Global Climate Change, São Paulo, (U.S. Environmental Protection Agency, 1990), pp. 93-104.

5. R. A. Houghton, In Proceedings of the IPCC Conference on Tropical Forestry Response Options to Global Climate Change, São Paulo (U.S. Environmental Protection Agency, 1990), pp. 88-92.
6. IPCC, First Assessment Report, Working Group III, The IPCC Response Strategies (1990), pp. 97-102; www.ipcc.ch/site/assets/uploads/2018/03/ipcc_far_wg_ll_full_report.pdf.

7. IPCC, Global Warming of $1.5^{\circ} \mathrm{C}$ : An IPCC Special Report on the Impacts of Global Warming of $1.5^{\circ} \mathrm{C}$ Above Pre-Industrial Levels and Related Global Greenhouse Gas Emission Pathways, in the Context of Strengthening the Global Response to the Threat of Climate Change, Sustainable Development, and Efforts to Eradicate Poverty, V. Masson-Delmotte et al., Eds. (World Meteorological Organization, Geneva, 2018).

8. S. Brown, A. J. R. Gillespie, A. E. Lugo, Biomass of tropical forests of south and southeast Asia. Can. J. For. Res. 21, 111-117 (1991). doi:10.1139/x91-015

9. L. R. Iverson, S. Brown, A. Prasad, H. Mitasova, A. J. R. Gillespie, A. E. Lugo, in Effects of Land Use Change on Atmospheric $\mathrm{CO}_{2}$ Concentrations: Southeast Asia as a Case Study (Springer, 1994), pp. 67-116.

10. L. R. Iverson, S. Brown, A. Grainger, A. Prasad, D. Liu, Carbon sequestration in tropical Asia: An assessment of technically suitable forest lands using geographic information systems analysis. Clim. Res. 3, 23-38 (1993). doi: $10.3354 / \mathrm{cr} 003023$

11. R. Chazdon, P. Brancalion, Restoring forests as a means to many ends. Science 365, 24-25 (2019). doi:10.1126/science.aax9539 Medline

12. C. Sargent, M. Lowcock, In Proceedings of the Technical Workshop to Explore Options for Global Forestry Management, Bangkok (International Institute for Environment and Development, 1991), pp. 163-185.

13. A. Grainger, In Forest Ecosystems, Forest Management and the Global Climate Cycle (Springer, 1996), pp. 335-348.

14. C. G. Van Kooten, A. Grainger, E. Ley, G. Marland, B. Solberg, Conceptual issues related to carbon sequestration: Uncertainty and time. Crit. Rev. Environ. Sci. Technol. 27 (suppl. 1), 65-82 (1997). doi:10.1080/10643389709388510

15. A. Grainger, The prospect of global environmental relativities after an Anthropocene tipping point. For. Policy Econ. 79, 36-49 (2017). doi:10.1016/j.forpol.2017.01.008

22 July 2019; accepted 7 October 2019

Published online 18 October 2019

10.1126/science.aay8334 


\section{Science}

\section{Comment on "The global tree restoration potential"}

Alan Grainger, Louis R. Iverson, Gregg H. Marland and Anantha Prasad

Science 366 (6463), eaay8334

DOI: $10.1126 /$ science.aay8334

\section{RELATED}

CONTENT

REFERENCES

PERMISSIONS http://science.sciencemag.org/content/sci/366/6463/eaay7976.full http://science.sciencemag.org/content/sci/366/6463/eaaz0388.full http://science.sciencemag.org/content/sci/366/6463/eaay8108.full http://science.sciencemag.org/content/sci/365/6448/76.full

This article cites 6 articles, 2 of which you can access for free $\mathrm{http}: / /$ science.sciencemag.org/content/366/6463/eaay8334\#BIBL

http://www.sciencemag.org/help/reprints-and-permissions

Use of this article is subject to the Terms of Service

Science (print ISSN 0036-8075; online ISSN 1095-9203) is published by the American Association for the Advancement of Science, 1200 New York Avenue NW, Washington, DC 20005. The title Science is a registered trademark of AAAS.

Copyright (C) 2019 The Authors, some rights reserved; exclusive licensee American Association for the Advancement of Science. No claim to original U.S. Government Works 


\title{
Response to Comments on "The global tree restoration potential"
}

\author{
Jean-Francois Bastin ${ }^{1 *}$, Yelena Finegold ${ }^{2}$, Claude Garcia ${ }^{3}$, Nick Gellie ${ }^{4}$, Andrew Lowe ${ }^{5}$, \\ Danilo Mollicone ${ }^{2}$, Marcelo Rezende ${ }^{2}$, Devin Routh ${ }^{1}$, Moctar Sacande ${ }^{2}$, Ben Sparrow ${ }^{4}$, \\ Constantin M. Zohner', Thomas W. Crowther ${ }^{1}$
}

${ }^{1}$ Crowther Lab, Department of Environmental Systems Science, Institute of Integrative Biology, ETH Zürich, Zürich, Switzerland. ${ }^{2}$ Food and Agriculture Organization of the United Nations, Rome, Italy. ${ }^{3}$ Department of Environmental Systems Science, Institute of Integrative Biology, ETH Zürich, Zürich, Switzerland. ${ }^{4}$ Terrestrial Ecosystem Research Network, School of Biological Sciences, University of Adelaide, Adelaide, SA 5005, Australia. ${ }^{5}$ Environment Institute and School of Biological Sciences, University of Adelaide, Adelaide, SA 5005, Australia.

*Corresponding author. Email: bastin.j@ggmail.com

Our study quantified the global tree restoration potential and its associated carbon storage potential under existing climate conditions. We received multiple technical comments, both supporting and disputing our findings. We recognize that several issues raised in these comments are worthy of discussion. We therefore provide a detailed common answer where we show that our original estimations are accurate.

Our study exploring the global tree restoration potential (I) inspired many discussions within and beyond the scientific community. Here, we provide a point-by-point response to several technical comments that were raised (2-4). However, we first want to highlight a theme that pervades the technical comments, which stems from a lack of clarity in our original text. Given the potential to capture more than 200 gigatonnes of carbon (GtC) at full maturity, we suggested in the abstract that global tree restoration is our most effective climate change solution to date. In saying this, we intended to highlight that we are aware of no other viable climate change solution that is quantitatively as large in terms of carbon drawdown. We did not suggest that tree restoration should be considered as the unique solution to climate change. To avoid this confusion, we have corrected the abstract accordingly.

The real value of our analysis is to show that tree restoration may be a far more powerful carbon drawdown solution than previously expected. With the potential to capture $205 \mathrm{GtC}$ at full maturity, tree restoration constitutes an important component in the fight against climate change. Restoring even $10 \%$ of the 900 Mha of available land could draw down a meaningful proportion of the $\sim 300 \mathrm{GtC}$ that was added to the atmosphere as a result of human activity (5). "Project Drawdown" lists the leading climate change solutions (6), which are ranked in terms of the quantity of carbon dioxide equivalent. Effective "refrigeration management" is highlighted as the leading solution, with the potential to save $89 \mathrm{GtCO}_{2}$ (i.e., $\sim 24 \mathrm{GtC}$ ) by 2050 . Until now, forest restoration has been broken down by region and listed below the top solutions. However, the maximum global potential (1) of regenerating forests is likely to be as high as any other solution in terms of carbon capture alone. Our study provides quantitative evidence to support this point and the claim by Lewis et al. (7) that "restoring natural forests is the best way to remove atmospheric carbon."

By revealing the potential of restoration as a carbon drawdown solution, our study does not preclude the urgent need to reduce greenhouse gas emissions from the combustion of fossil fuels, from deforestation and forest degradation. There is no compromise or trade-off between the two. This has notably been well understood by the European Commission that, following our study, has published a communication entitled "Stepping up EU Action to Protect and Restore the World's Forests" where conservation and restoration of forests are both proposed as concrete actions (8).

We also stress that restoration does not mean planting trees everywhere. As highlighted in our analysis, there are many regions where tree cover is not suitable. Restoration can be natural or assisted, but it means only allowing ecosystems to recover to a natural state, including ecosystems with $0 \%$ of tree cover.

Finally, before providing detailed responses to specific issues raised, we think it is critical to highlight that although there is still ongoing debate about the exact carbon drawdown potential of trees, the scientific community is not divided on the importance of responsible global resto- 
ration as an extremely valuable carbon drawdown solution that must be combined with emissions cuts in the fight against climate change.

\section{The carbon drawdown potential of forest restoration compared to atmospheric stocks}

Friedlingstein et al. (3) emphasize that restored trees cannot capture two-thirds of anthropogenic carbon emissions. They point out that a considerable proportion of anthropogenic emissions is absorbed each year by the land and ocean, and so only $45 \%$ of the emitted carbon remains in the atmosphere. This point is entirely correct, and we absolutely recognize the constant airborne fraction of $45 \%$. However, our statement, "reaching this maximum restoration potential would reduce a considerable proportion of the global anthropogenic carbon burden ( $300 \mathrm{GtC})$ to date," certainly does not contradict their point. We simply state that, if we could store an extra $205 \mathrm{GtC}$ in newly formed ecosystems, this process would indeed reduce a considerable amount of the excess carbon that resides in the atmosphere following human activity. To provide an order of magnitude, we clarified that the total excess carbon remaining in the atmosphere is approximately $300 \mathrm{GtC}$, as highlighted in the Fifth Assessment Report of the Intergovernmental Panel on Climate Change (9).

\section{On our estimation of potential carbon drawdown from global forest restoration}

Friedlingstein et al., Lewis et al., and Veldman et al. (2-4) claim that our global estimate of total potential carbon in restoration areas is too high. The discrepancies between our estimate and their estimates arise from (i) misinterpretations or confusion between the definitions of forest cover and associated carbon pools, and (ii) a lack of sufficient detail in the original manuscript on how existing carbon in potential restoration areas was removed for estimating the global restoration potential. We clarify these points here.

Lewis et al. cite several studies $(7,10,11)$ that appear to report lower forest carbon values than the ones we used. As such, once extrapolated to the 900 Mha that we report as canopy cover available for restoration, this leads to a considerably lower total carbon potential than our estimate (1). However, we emphasize that none of these studies contradicts our estimations. In fact, the differences arise because of some misconceptions in the interpretation of Lewis et al., which we outline below:

1) Three of the four examples provided are based on a different definition of forest: namely forest area, rather than tree canopy cover. Global forest area (land containing at least $10 \%$ tree cover) across the globe is considerably larger than global tree canopy cover (cumulative tree cover). We estimated that there is 1657 Mha of forest area available [ta- ble S2 of (1)], which contains 900 Mha available as cumulative tree canopy cover. Because these papers $(7,10,11)$ were addressing forest area, the carbon density estimates would need to be scaled to 1657 Mha instead of 900 Mha. Correcting for this consideration of forest area almost doubles the carbon estimates proposed by Lewis $e t$ al.

2) The numbers provided by Lewis et al. in their restoration study (7) concern only two of the five carbon pools for vegetation ecosystems (i.e., aboveground and belowground plant biomass). Restoring forest ecosystems would actually have an impact on all five pools of carbon, including soil, litter, and dead wood (12). In our analysis, we included all five, which drastically increases the amount of carbon expected to be stored in restored forests.

3) Lewis et al. state that sequestering $205 \mathrm{GtC}$ by restoring natural forests across the globe is unrealistic because anthropogenic land-use change since 1750 has emitted only $200 \mathrm{GtC}$ in total (13). We think this assumption is flawed. In many regions, substantial deforestation occurred before $1750(14,15)$. But more important, as with all global historical estimates, the uncertainty in this IPCC estimate is considerable because of our limited knowledge of the changes in vegetation ecosystem carbon storage over such a long historical time period. This uncertainty only highlights the need for more quantitative analyses, such as the present study, that are needed to refine these early IPCC estimates. As new data and analytical approaches become available, they will be increasingly critical for refining our understanding of the global changes in land carbon storage.

All three technical comments raise the importance of removing the carbon content that currently exists in potential restoration areas in order to calculate the gain associated with tree restoration. Although it was not fully clear in our manuscript, we agree with this. To clarify, we provide a more detailed description of our approach and of related uncertainties. We show that our $205 \mathrm{GtC}$ estimate is a conservative estimate of the additional carbon that could be stored by ecosystems supporting trees.

\section{Calculation of the carbon potentially stored in areas available for restoration}

To calculate the amount of carbon that could be potentially stored in areas available for forest restoration, we use the potential tree cover available for restoration in each pixel [figure 2B of (1)]. We then estimate the amount of carbon that could be stored in each pixel through a "tree cover carbon equivalent" calculation. To consider uncertainties, we associate three different baselines of "tree cover - carbon equivalent" with the average carbon density observed in protected areas within the Boreal, Dry, Temperate, and Tropical biomes $(16,17)$ (Table 1$)$. We calculate the median, the 75th percentile, and the 95th percentile of tree cover in 
forests. This can then be used to scale the tree cover estimates to existing biome-level estimates of carbon storage (Table 1).

By upscaling this calculation to the global area available for restoration, we infer the total amount of carbon that could be stored in restored ecosystems:

- $349 \mathrm{GtC}$ for the median tree cover - average carbon equivalent per biome;

- $239 \mathrm{GtC}$ for the 75th percentile tree cover - average carbon equivalent per biome;

- $206 \mathrm{GtC}$ for the 95th percentile tree cover - average carbon equivalent per biome.

Thus, we estimate that the total carbon that could be stored in areas available for restoration ranges between 206 and $349 \mathrm{GtC}$.

\section{Carbon to remove}

Carbon currently existing in potential restoration areas must be subtracted from the above-mentioned values to estimate the global extra carbon storage potential. We estimated the amount of carbon currently held in vegetation using the IPCC global biomass map (18) and the carbon held in soil using the soilgrid layers (19). Summing these two layers gives us the total amount of carbon per pixel that currently exists in areas available for restoration. Globally, we infer a total of $5.7 \mathrm{GtC}$ currently present in vegetation and $67.1 \mathrm{GtC}$ present in soils.

\section{Final calculation}

After subtraction of the existing carbon content from the potential global carbon content that could be stored in areas available for restoration, the global carbon gain from tree restoration potential ranges between 133.2 and $276.2 \mathrm{GtC}$ with a mid-range value of $204.7 \mathrm{GtC}$. This range reflects the uncertainty in calibrating the biome-specific carbon density values to a baseline percent tree cover (see Table 1).

\section{On the potential effect of albedo and evapotranspiration}

Friedlingstein et al. and Veldman et al. $(3,4)$ raise the important point that forests have an impact on climate not only through changes in the carbon cycle, but also through changes in evapotranspiration and albedo.

We completely agree that changes in forest cover resulting from restoration would also affect the climate through a range of mechanisms including changes in surface albedo and evapotranspiration. Indeed, because of a mixture of biochemical and biophysical impacts, it is possible that forest restoration could have a warming impact in some areas, especially at higher latitudes. Although these are important avenues for future research, calculating the changes in albedo and evapotranspiration associated with restoration is beyond the scope of the present study. Our analysis only highlighted the potential for considerable carbon drawdown in restoring trees. But we hope that our analysis provides a stepping stone to future research efforts to evaluate how global tree restoration might affect the climate.

\section{Should drylands be considered for tree restoration?}

Veldman et al. (4) criticize our results in dryland biomes, stating that many of these areas simply should not be considered suitable for tree restoration. Generally, we must highlight that our analysis does not ever address whether any actions "should" or "should not" take place. Our analysis simply estimated the biophysical limits of global forest growth by highlighting where trees "can" exist. However, we disagree with the suggestion of Veldman et al. for a number of reasons:

1) Veldman et al. neglect that large areas of dryland that are classed as savannas have, since the 1970s, been designated by UNEP as suffering from various degrees of vegetation and soil degradation, called desertification (20). Indeed, in the latest reports of the IPCC (21), it is stated with "high confidence" that the range and intensity of desertification has increased over the past decades (22). Desertification hotspots extended to about $9.2 \%$ of drylands $( \pm 0.5 \%)$, affecting about 500 million ( \pm 120 million) people in 2015 (21). Research since 1990 has suggested that restoring tree cover that would naturally exist on these lands would help in soil restoration (23). Veldman et al. also neglect the current vegetation encroachment trend in dryland regions that are unaffected by desertification (24). Indeed, the current climate differs from the climate of past decades, leading to a natural increase in land available for tree cover in some regions.

2) Veldman et al. stress that our model had low predictive power across many of the open-canopy biomes, suggesting that it fails to account for natural fire and the presence of large mammals. Here, they have misinterpreted the uncertainty of our model. First, natural fires and large mammals exist in protected areas. They are therefore indirectly accounted for in our model. Second, as natural fire cannot be distinguished from human-made fire, it cannot be accounted for as a variable of the model to extrapolate the natural tree cover outside protected areas. Third, the high uncertainty in intermediate tree cover is due to the general low occurrence of intermediate tree cover.

3) The authors suggest that the restoration of savanna ecosystems "requires tree-cutting and prescribed fire." However, contrary to the recommendation of Veldman and colleagues, we would not say what "should" be done by humans, we only say what is most likely to happen naturally if we remove the human factor from the equation (25).

We agree with Veldman et al. that forests should not replace natural grasslands. Our model does not contradict 
this statement at all. Indeed, our model only estimates where trees could exist, from a purely biophysical perspective. And by estimating from 0 to $100 \%$ of potential tree cover, our model also estimates the distribution of natural grasslands, which must absolutely be protected and conserved.

\section{On the future projection being uncertain}

Lewis et al. (2) caution against our interpretation of the risk of change in potential tree cover due to high uncertainty in future effects of climate change on natural ecosystems. Here we must agree that the uncertainty in our estimates is important, but this is already fully recognized in our paper (1). Our risk assessment is an extrapolation, not an interpolation, and there are considerable uncertainties in our model and in future climate projections. But it is important to note that this is not a projection of changes in tree cover. It is the expectation of differences in potential tree cover. That is, we are not estimating where trees will be lost and gained. Rather, we highlight where the potential for new forests might be altered under a different climate. As this "potential" is not subject to the same biological feedbacks that limit the changes in existing ecosystems, the future shifts are likely to be considerably more striking.

It is widely expected that a greening of the planet will happen, as increases in temperature and atmospheric $\mathrm{CO}_{2}$ lead to increased tree cover in high-latitude areas (26). Our model predicts this same phenomenon. However, our model provides new insights into this trend, suggesting that conditions are simultaneously becoming harsher in tropical regions. Indeed, hotter temperatures and severe droughts are very likely to have a negative impact on tropical forests (27). This has previously been demonstrated by studies showing that climate change is happening too fast to allow for renewal or replacement of tropical tree species [e.g., (28)].

Of course, when considering future changes in vegetation, it is important to recognize the importance of feedbacks. We stress in the paper that "it is possible that elevated $\mathrm{CO}_{2}$ concentrations under future climate scenarios might enhance the growth of those existing trees." A clear limitation is that we could not represent such $\mathrm{CO}_{2}$ fertilization effects in our model. Such feedbacks must be considered using process-based biogeochemical models to fully represent the mechanisms underpinning the future changes in vegetation. However, the uncertainty in these Earth System Model (ESM) projections of land carbon storage is exceptionally high (29), highlighting the need for independent data-driven approaches to evaluate such expectations. With high accuracy to predict potential forest cover, our model can serve as a useful independent approach.

\section{Conclusion}

We show that our global estimate of potential tree cover and carbon storage in restored ecosystems is accurate, supports the pre-2000 scientific literature (30), and does not contradict previous studies (7). This underscores the fact that restoration of natural tree cover should be considered as the most viable solution to remove atmospheric carbon. As a scientific contribution, we do not state what "should" be done at any location around the world, but instead highlight what is possible. We recognize that most issues raised in the comments by our colleagues are relevant and worthy of consideration. The differences in approaches and related estimates illustrate the uncertainty that remains and justify the need for more quantitative and data-driven approaches. Until now, most of our understanding of restoration potential stemmed from ESMs with high uncertainties (29) or from "expert opinion" pieces (7), which cannot reflect the full global potential for carbon capture. We consider that quantitative global approaches based on observations are needed to understand and promote restoration as one of the most promising tools at our disposal in the fight against climate change and biodiversity loss.

\section{REFERENCES}

1. J.-F. Bastin, Y. Finegold, C. Garcia, D. Mollicone, M. Rezende, D. Routh, C. M. Zohner, T. W. Crowther, The global tree restoration potential. Science 365, 7679 (2019). doi:10.1126/science.aax0848 Medline

2. S. L. Lewis, E. T. A. Mitchard, C. Prentice, M. Maslin, B. Poulter, Comment on "The global tree restoration potential". Science 366, eaaz0388 (2019).

3. P. Friedlingstein, M. Allen, J. G. Canadell, G. P. Peters, S. I. Seneviratne, Comment on "The global tree restoration potential". Science 366, eaay8060 (2019).

4. J. W. Veldman, J. C. Aleman, S. T. Alvarado, T. M. Anderson, S. Archibald, W. J. Bond, T. W. Boutton, N. Buchmann, E. Buisson, J. G. Canadell, M. de Sá Dechoum, M. H. Diaz-Toribio, G. Durigan, J. J. Ewel, G. W. Fernandes, A. Fidelis, F. Fleischman, S. P. Good, D. M. Griffith, J.-M. Hermann, W. A. Hoffmann, S. Le Stradic, C. E. R. Lehmann, G. Mahy, A. N. Nerlekar, J. B. Nippert, R. F. Noss, C. P. Osborne, G. E. Overbeck, C. L. Parr, J. G. Pausas, R. T. Pennington, M. P. Perring, F. E. Putz, J. Ratnam, M. Sankaran, I. B. Schmidt, C. B. Schmitt, F. A. O. Silveira, A. C. Staver, N. Stevens, C. Still, C. A. E. Strömberg, V. M. Temperton, J. M. Varner, N. P. Zaloumis, Comment on "The global tree restoration potential". Science 366, eaay7976 (2019).

5. IPCC, Global Warming of $1.5^{\circ} \mathrm{C}$ : An IPCC Special Report on the Impacts of Global Warming of $1.5^{\circ} \mathrm{C}$ Above Pre-Industrial Levels and Related Global Greenhouse Gas Emission Pathways, in the Context of Strengthening the Global Response to the Threat of Climate Change, Sustainable Development, and Efforts to Eradicate Poverty, V. Masson-Delmotte et al., Eds. (World Meteorological Organization, Geneva, 2018)

6. P. Hawken, Drawdown: The Most Comprehensive Plan Ever Proposed to Reverse Global Warming (Penguin, 2016).

7. S. L. Lewis, C. E. Wheeler, E. T. A. Mitchard, A. Koch, Restoring natural forests is the best way to remove atmospheric carbon. Nature 568, 25-28 (2019). doi:10.1038/d41586-019-01026-8 Medline

8. European Commission, "EU Communication (2019) on stepping up EU action to protect and restore the world's forests" (2019); https://ec.europa.eu/info/publications/eu-communication-2019-stepping-euaction-protect-and-restore-worlds-forests_en. 
9. IPCC, Climate Change 2013: The Physical Science Basis. Contribution of Working Group I to the Fifth Assessment Report of the Intergovernmental Panel on Climate Change, T. F. Stocker et al., Eds. (Cambridge Univ. Press, 2014). doi:10.1017/CB09781107415324

10. B. W. Griscom, J. Adams, P. W. Ellis, R. A. Houghton, G. Lomax, D. A. Miteva, W. H. Schlesinger, D. Shoch, J. V. Siikamäki, P. Smith, P. Woodbury, C. Zganjar, A. Blackman, J. Campari, R. T. Conant, C. Delgado, P. Elias, T. Gopalakrishna, M. R. Hamsik, M. Herrero, J. Kiesecker, E. Landis, L. Laestadius, S. M. Leavitt, S. Minnemeyer, S. Polasky, P. Potapov, F. E. Putz, J. Sanderman, M. Silvius, E. Wollenberg, J. Fargione, Natural climate solutions. Proc. Natl. Acad. Sci. U.S.A. 114, 11645-11650 (2017). doi:10.1073/pnas.1710465114 Medline

11. V. K. Arora, A. Montenegro, Small temperature benefits provided by realistic afforestation efforts. Nat. Geosci. 4, 514-518 (2011). doi:10.1038/ngeo1182

12. L. E. Nave, G. M. Domke, K. L. Hofmeister, U. Mishra, C. H. Perry, B. F. Walters, C. W. Swanston, Reforestation can sequester two petagrams of carbon in US topsoils in a century. Proc. Natl. Acad. Sci. U.S.A. 115, 2776-2781 (2018). doi:10.1073/pnas.1719685115 Medline

13. C. Le Quéré, R. M. Andrew, J. G. Canadell, S. Sitch, J. I. Korsbakken, G. P. Peters, A. C. Manning, T. A. Boden, P. P. Tans, R. A. Houghton, R. F. Keeling, S. Alin, O. D. Andrews, P. Anthoni, L. Barbero, L. Bopp, F. Chevallier, L. P. Chini, P. Ciais, K. Currie, C. Delire, S. C. Doney, P. Friedlingstein, T. Gkritzalis, I. Harris, J. Hauck, V. Haverd, M. Hoppema, K. Klein Goldewijk, A. K. Jain, E. Kato, A. Körtzinger, P. Landschützer, N. Lefèvre, A. Lenton, S. Lienert, D. Lombardozzi, J. R. Melton, N. Metzl, F. Millero, P. M. S. Monteiro, D. R. Munro, J. E. M. S. Nabel, S. Nakaoka, K. O'Brien, A. Olsen, A. M. Omar, T. Ono, D. Pierrot, B. Poulter, C. Rödenbeck, J. Salisbury, U. Schuster, J. Schwinger, R. Séférian, I. Skjelvan, B. D. Stocker, A. J. Sutton, T. Takahashi, H. Tian, B. Tilbrook, I. T. van der Laan-Luijkx, G. R. van der Werf, N. Viovy, A. P. Walker, A. J. Wiltshire, S. Zaehle, Global Carbon Budget 2016. Earth Syst. Sci. Data 8, 605-649 (2016). doi:10.5194/essd-8-605-2016

14. J. O. Kaplan, K. M. Krumhardt, N. Zimmermann, The prehistoric and preindustrial deforestation of Europe. Quat. Sci. Rev. 28, 3016-3034 (2009). doi:10.1016/i.quascirev.2009.09.028

15. A. Koch, C. Brierley, M. M. Maslin, S. L. Lewis, Earth system impacts of the European arrival and Great Dying in the Americas after 1492. Quat. Sci. Rev. 207, 13-36 (2019). doi:10.1016/j.quascirev.2018.12.004

16. Y. Pan, R. A. Birdsey, J. Fang, R. Houghton, P. E. Kauppi, W. A. Kurz, O. L. Phillips, A. Shvidenko, S. L. Lewis, J. G. Canadell, P. Ciais, R. B. Jackson, S. W. Pacala, A. D. McGuire, S. Piao, A. Rautiainen, S. Sitch, D. Hayes, A large and persistent carbon sink in the world's forests. Science 333, 988-993 (2011). doi:10.1126/science.1201609 Medline

17. J. Grace, J. S. Jose, P. Meir, H. S. Miranda, R. A. Montes, Productivity and carbon fluxes of tropical savannas. J. Biogeogr. 33, 387-400 (2006). doi:10.1111/j.13652699.2005.01448.x

18. A. Ruesch, H. K. Gibbs, “New IPCC Tier-1 Global Biomass Carbon Map For the Year 2000" (Oak Ridge National Laboratory, 2008).

19. T. Hengl, J. Mendes de Jesus, G. B. M. Heuvelink, M. Ruiperez Gonzalez, M. Kilibarda, A. Blagotić, W. Shangguan, M. N. Wright, X. Geng, B. BauerMarschallinger, M. A. Guevara, R. Vargas, R. A. MacMillan, N. H. Batjes, J. G. B. Leenaars, E. Ribeiro, I. Wheeler, S. Mantel, B. Kempen, SoilGrids250m: Global gridded soil information based on machine learning. PLOS ONE 12, e0169748 (2017). doi:10.1371/journal.pone.0169748 Medline

20. United Nations Conference on Desertification, "Round-up, Plan of Action and Resolutions" (1978).

21. IPCC, Climate Change and Land: An IPCC Special Report on Climate Change, Desertification, Land Degradation, Sustainable Land Management, Food Security, and Greenhouse Gas Fluxes In Terrestrial Ecosystems (2019); www.ipcc.ch/report/srccl/.

22. H. K. Gibbs, J. M. Salmon, Mapping the world's degraded lands. Appl. Geogr. 57, 12-21 (2015). doi:10.1016/j.apgeog.2014.11.024

23. R. Lal, Restoring Soil Quality to Mitigate Soil Degradation. Sustainability 7, 58755895 (2015). doi:10.3390/su7055875
24. Z. Zhu, S. Piao, R. B. Myneni, M. Huang, Z. Zeng, J. G. Canadell, P. Ciais, S. Sitch, P. Friedlingstein, A. Arneth, C. Cao, L. Cheng, E. Kato, C. Koven, Y. Li, X. Lian, Y. Liu, R. Liu, J. Mao, Y. Pan, S. Peng, J. Peñuelas, B. Poulter, T. A. M. Pugh, B. D. Stocker, N. Viovy, X. Wang, Y. Wang, Z. Xiao, H. Yang, S. Zaehle, N. Zeng, Greening of the Earth and its drivers. Nat. Clim. Chang. 6, 791-795 (2016). doi:10.1038/nclimate3004

25. M. F. Breed, A. J. Lowe, P. E. Mortimer, Restoration: 'Garden of Eden' unrealistic. Nature 533, 469 (2016). doi:10.1038/533469d Medline

26. X.-P. Song, M. C. Hansen, S. V. Stehman, P. V. Potapov, A. Tyukavina, E. F. Vermote, J. R. Townshend, Global land change from 1982 to 2016. Nature 560 639-643 (2018). doi:10.1038/s41586-018-0411-9 Medline

27. J.-F. Bastin, E. Clark, T. Elliott, S. Hart, J. van den Hoogen, I. Hordijk, H. Ma, S. Majumder, G. Manoli, J. Maschler, L. Mo, D. Routh, K. Yu, C. M. Zohner, T. W. Crowther, Understanding climate change from a global analysis of city analogues. PLOS ONE 14, e0217592 (2019). doi:10.1371/journal.pone.0217592 Medline

28. A. Esquivel-Muelbert, T. R. Baker, K. G. Dexter, S. L. Lewis, R. J. W. Brienen, T. R. Feldpausch, J. Lloyd, A. Monteagudo-Mendoza, L. Arroyo, E. Álvarez-Dávila, N. Higuchi, B. S. Marimon, B. H. Marimon-Junior, M. Silveira, E. Vilanova, E. Gloor, Y. Malhi, J. Chave, J. Barlow, D. Bonal, N. Davila Cardozo, T. Erwin, S. Fauset, B. Hérault, S. Laurance, L. Poorter, L. Qie, C. Stahl, M. J. P. Sullivan, H. Ter Steege, V. A. Vos, P. A. Zuidema, E. Almeida, E. Almeida de Oliveira, A. Andrade, S. A. Vieira, L. Aragão, A. Araujo-Murakami, E. Arets, G. A. Aymard C, C. Baraloto, P. B. Camargo, J. G. Barroso, F. Bongers, R. Boot, J. L. Camargo, W. Castro, V. Chama Moscoso, J. Comiskey, F. Cornejo Valverde, A. C. Lola da Costa, J. Del Aguila Pasquel, A. Di Fiore, L. Fernanda Duque, F. Elias, J. Engel, G. Flores Llampazo, D. Galbraith, R. Herrera Fernández, E. Honorio Coronado, W. Hubau, E. JimenezRojas, A. J. N. Lima, R. K. Umetsu, W. Laurance, G. Lopez-Gonzalez, T. Lovejoy, O. Aurelio Melo Cruz, P. S. Morandi, D. Neill, P. Núñez Vargas, N. C. Pallqui Camacho, A. Parada Gutierrez, G. Pardo, J. Peacock, M. Peña-Claros, M. C. Peñuela-Mora, P. Petronelli, G. C. Pickavance, N. Pitman, A. Prieto, C. Quesada, H. Ramírez-Angulo, M. Réjou-Méchain, Z. Restrepo Correa, A. Roopsind, A. Rudas, R. Salomão, N. Silva, J. Silva Espejo, J. Singh, J. Stropp, J. Terborgh, R. Thomas, M. Toledo, A. Torres-Lezama, L. Valenzuela Gamarra, P. J. van de Meer, G. van der Heijden, P. van der Hout, R. Vasquez Martinez, C. Vela, I. C. G. Vieira, O. L. Phillips, Compositional response of Amazon forests to climate change. Glob. Change Biol. 25, 39-56 (2018). doi:10.1111/gcb.14413 Medline

29. K. E. O. Todd-Brown, J. T. Randerson, W. M. Post, F. M. Hoffman, C. Tarnocai, E. A. G. Schuur, S. D. Allison, Causes of variation in soil carbon simulations from CMIP5 Earth system models and comparison with observations. Biogeosciences 10, 1717-1736 (2013). doi:10.5194/bg-10-1717-2013

30. A. Grainger, L. R. Iverson, G. H. Marland, A. Prasad, Comment on "The global tree restoration potential". Science 366, eaay8334 (2019).

2 August 2019; accepted 2 October 2019

Published online 18 October 2019

10.1126/science.aay8108 
Table 1. Tree cover statistics summary observed within the $\sim 78,000$ photo-interpreted points.

\begin{tabular}{|l|c|c|c|c|c|}
\hline \multicolumn{1}{|c|}{ Biome } & $\begin{array}{c}\text { Canopy } \\
\text { cover } \\
(\text { Mha })\end{array}$ & $\begin{array}{c}\text { Median } \\
\text { tree } \\
\text { cover } \\
(\%)\end{array}$ & $\begin{array}{c}\text { 75th } \\
\text { percentile } \\
\text { tree } \\
\text { cover }(\%)\end{array}$ & $\begin{array}{c}\text { 95th } \\
\text { percentile } \\
\text { tree } \\
\text { cover (\%) }\end{array}$ & $\begin{array}{c}\text { Carbon } \\
\text { density } \\
\left(\text { tC ha } \text { h }^{-1}\right)\end{array}$ \\
\hline Boreal forests/taiga & 178 & 90 & 100 & 100 & 239.2 \\
\hline Desert and xeric shrublands & 77.6 & 20 & 65 & 90 & 202.4 \\
\hline Flooded grasslands and savannas & 9 & 55 & 100 & 100 & 202.4 \\
\hline Mangroves & 2.6 & 100 & 100 & 100 & 282.5 \\
\hline Mediterranean forests, woodlands, and scrub & 18.8 & 55 & 90 & 90 & 202.4 \\
\hline Montane grasslands and shrublands & 19.3 & 90 & 100 & 100 & 202.4 \\
\hline Temperate broadleaf and mixed forests & 109 & 86 & 100 & 100 & 154.7 \\
\hline Temperate conifer forests & 35.9 & 100 & 100 & 100 & 154.7 \\
\hline Temperate grasslands, savannas, and shrublands & 72.5 & 80 & 100 & 100 & 154.7 \\
\hline Tropical and subtropical coniferous forests & 7.1 & 100 & 100 & 100 & 282.5 \\
\hline Tropical and subtropical dry broadleaf forests & 32.8 & 100 & 100 & 100 & 282.5 \\
\hline Tropical and subtropical grasslands, savannas, and & 189.5 & 45 & 90 & 100 & 282.5 \\
\hline shrublands & & & & & \\
\hline Tropical and subtropical moist broadleaf forests & 97.1 & 100 & 100 & 100 & 282.5 \\
\hline Tundra & 50.6 & 80 & 100 & 100 & 239.2 \\
\hline
\end{tabular}




\section{Science}

\section{Response to Comments on "The global tree restoration potential"}

Jean-Francois Bastin, Yelena Finegold, Claude Garcia, Nick Gellie, Andrew Lowe, Danilo Mollicone, Marcelo Rezende, Devin Routh, Moctar Sacande, Ben Sparrow, Constantin M. Zohner and Thomas W. Crowther

Science 366 (6463), eaay8108.

DOI: $10.1126 /$ science.aay8108

ARTICLE TOOLS

RELATED
CONTENT

REFERENCES

PERMISSIONS http://science.sciencemag.org/content/366/6463/eaay8108

http://science.sciencemag.org/content/sci/366/6463/eaay8060.full http://science.sciencemag.org/content/sci/366/6463/eaay7976.full http://science.sciencemag.org/content/sci/366/6463/eaaz0388.full http://science.sciencemag.org/content/sci/365/6448/76.full http://science.sciencemag.org/content/sci/366/6463/eaay8334.full

This article cites 24 articles, 8 of which you can access for free http://science.sciencemag.org/content/366/6463/eaay8108\#BIBL

http://www.sciencemag.org/help/reprints-and-permissions

Use of this article is subject to the Terms of Service

Science (print ISSN 0036-8075; online ISSN 1095-9203) is published by the American Association for the Advancement of Science, 1200 New York Avenue NW, Washington, DC 20005. The title Science is a registered trademark of AAAS.

Copyright (C) 2019 The Authors, some rights reserved; exclusive licensee American Association for the Advancement of Science. No claim to original U.S. Government Works 